\title{
o4. TV dizi adlarındaki kelime türlerinin tahlil ve tasnifi
}

\section{Gülșah PARLAK KALKAN ${ }^{1}$}

\begin{abstract}
APA: Parlak Kalkan, G. (2021). TV dizi adlarındaki kelime türlerinin tahlil ve tasnifi. RumeliDE Dil ve Edebiyat Araşturmaları Dergisi, (22), 67-95. DOI: 10.29000/rumelide.885506.
\end{abstract}

\section{$\ddot{\mathbf{O} z}$}

Karşılıklı olmanın zorunlu olmadığı durumlarda iletişimi bilhassa kitlesel düzeyde gerçekleştiren araçlara kitle iletişim araçları denmektedir. Tüm dünyada olduğu gibi ülkemizde de uzun yıllardır ulaşılabilirlik bakımından en kolay ve en ucuz olan kitle iletişim aracı televizyondur. Türkiye'de 2015 yılında yapılan bir araştırma neticesinde ise ekrana gelen 8 bin 500 programın \%40’ını diziler oluşturmaktadır. Türk insanının büyük bir çoğunluğunun alacağı kararlardan yaşam şekline kadar pek çok mevzuda takipçisi olduğu dizilerden etkilendiği düşünüldüğünde Türkçenin her bakımdan durumunu öncelikle bu programlar açısından değerlendirmek elzemdir. Konuyla ilgili literatür incelendiğinde ise kitle iletişim araçlarındaki kültürel motiflerin tespitiyle ilgili pek çok kıymetli çalışma bulunmaktadır. Ancak güncel dilin durumunu ve dinamizmini somut bir şekilde tespit etmeye yönelik çalışmalar için önemli bir saha oluşturan kitle iletişim araçlarında Türkçe ile ilgili çalışmaların da sayısını arttırmak gerekmektedir. Bu maksatla söz konusu çalışmada, Türkiye'de reyting siralamasinda önde olan ATV, Fox, Kanal D, Kanal 7, Show TV, Star TV ve TRT 1 kanallarında dünden bugüne yayınlanan dizi adlarındaki kelimelerin tür bakımından tasnifi amaçlanmıştır. Bu doğrultuda ilgili kanallara ait internet sitelerinden derlenen toplam 576 dizi adındaki kelimeler, Zeynep Korkmaz’ın Türkiye Türkçesi Grameri-Şekil Bilgisi eserindeki sinıflandırmaya uygun olarak "Anlamlı Kelimeler (Adlar, Fiiller, Sifatlar, Zamirler, Zarflar)”, "Görevli Kelimeler (Bağlaçlar, Edatlar)” ve “Anlamlı-Görevli Kelimeler (Ünlemler)” şeklinde kategorize edilmiştir. Neticede dizi adlarında kullanılan kelimelerin kavram alanı, sözlükte madde başı olan kelime çeşitliliği ve kelimelerin tür dağılımı ile ilgili istatistiksel tespitlere ulaşılmıştır.

Anahtar kelimeler: TV, söz varlı̆̆ı, Türkçe, tür adı

\section{Analyse and classification of word types in the names of tv serials}

\begin{abstract}
In cases where mutuality is not obligatory, especially on a mass level is called a communication tool that performs the mass media. As in the World, television has been the easiest and cheapest mass communication tool in our country for many years. In 2015, the series consists of $40 \%$ of the broadcasted 8 thousand 500 programs in Turkey. Considering that the vast majority of Turkish people are affected by the TV series they follow on many issues from their decisions to their lifestyle, it is essential to evaluate the situation of Turkish in all respects primarily in terms of these programs. When the literature on the subject is examined, there are many valuable studies on the determination of cultural motifs in mass media. However, it is necessary to increase the number of studies on Turkish in mass communication tools, which constitutes an important field for studies to determine the status and dynamism of the current language in a concrete way. For this purpose, in
\end{abstract}

Dr. Öğr. Üyesi., Kilis 7 Aralık Üniversitesi, Muallim Rıfat Eğitim Fakültesi., Türkçe ve Sosyal Bilimler Eğitimi Bölümü, Türkçe Eğitimi ABD (Kilis, Türkiye), gulsah.parlak@hotmail.com, ORCID ID: oooo-00o3-0986-9768 [Araştırma makalesi, Makale kayıt tarihi: 08.01.2020-kabul tarihi: 20.03.2021; DOI: 10.29000/rumelide.885506.]

Adres | Address

RumeliDE Dil ve Edebiyat Araşttrmaları Dergisi $\quad$ RumeliDE Journal of Language and Literature Studies Osmanağa Mahallesi, Mürver Çiçeği Sokak, No:14/8 Osmanağa Mahallesi, Mürver Çiçeği Sokak, No:14/8

Kadıköy - İSTANBUL / TÜRKIYE 34714 Kadıköy - ISTANBUL / TURKEY 34714 e-posta: editor@rumelide.com

e-mail: editor@rumelide.com,

tel: +90 505 7958124, +90 2167730616 phone: +90 505 7958124, +90 2167730616 


\begin{abstract}
this study. In this study, it is aimed to sort out series names according to their genres. Those series were selected from main TV channels such as ATV, Fox, Kanal D, Kanal 7, Show TV, Star TV and TRT 1. Accordingly, 576 series were collected from internet sites of above mentioned channels and were categorised as 'significative words (noun, verb, adjective, pronoun, adverb)', 'functionary words (conjunction, preposition) and 'significative-functionary words (interjection) in accordance with classification of Zeynep Korkmaz's 'Turkish Grammar-knowledge of form'. Data achieved by the procedure of document analysis were evaluated according to phenomenological study which is one of the qualitative research techniques. Finally, statistical data were achieved related to conceptual field of words used in series names, word diversity in headword and distribution of genre.
\end{abstract}

Keywords: TV, vocabulary, Turkish, genre

\title{
Giriş
}

Dil, geçmiş ile gelecek arasında köprü kurarak kültürün temelini oluşturan tabii bir vasıta, kendine özgü kuralları olan ve sadece bu kurallara bağlı olarak gelişen canlı bir varlık, ne zaman ve nasıl geliştiği bilinmeyen gizli antlaşmalar sistemi, seslerden oluşan içtimai bir müessese (Ergin, 2012:3); düşünce, duygu ve isteklerin, topluma özgü ortak öğeler ve kurallarla başkalarına iletilmesini sağlayan gelişmiş bir dizge (Aksan, 2003:55); bazı ses ve ses öbeklerinin herhangi bir nesnenin, durumun ya da duygunun hayalini uyandırması (Kaplan, 2010:135) şeklinde tanımlanmaktadır. Yüzey yapıda bildirişim, derin yapıda ise insan-varlık-toplum/millî kimlik ilişkilerindeki işlevi ile iki temel fonksiyonu bulunan dil, hem birey hem de millet bilincine erişmiş toplumlar üzerinde kimlik belirleme ve temsil etme noktasında da ayırt edici bir vasıf taşımaktadır. Dil, insanın duygularını, düşüncelerini, isteklerini açığa vurmasına, yaşamını sürdürebilmesine olanak sağlayarak insanı insan yapan niteliklerin en başında gelmekte (Buran ve Yüksel Çak, 2012:94-95); aynı zamanda insan topluluklarının bir araya gelerek millet olma serüveninde de en önemli unsur olarak karşımıza çıkmaktadır. Buna bağlı olarak belli bir coğrafyada ortak anlaşma aracı olan dil ile gelişen kültürün yine dil ile geçmiş ve gelecek arasında köprü kurarak millî benliği koruduğunu, devamlılığını sağladığını söylemek mümkündür.

Her dilin kendine has bir söz varlı̆̆g vardır. Bir dildeki sözlerin bütünü, söz hazinesi, söz dağarcığı, kelime hazinesi, vokabüler (Türkçe Sözlük, 2005:1807) olarak tanımlanan söz varlığı; salt bir dildeki bir kısım seslerin oluşturduğu simgeler, kodlar ya da göstergeler değil (Aksan, 2006:7), aynı zamanda ait olduğu toplumun sosyolojik, kültürel, psikolojik, dinsel ve sanatsal eğilimleri ile hafızasında derin izler oluşturmuş tarihî olay ve durumların açığa çlkarılmasında (Kurt, 2019:133) ve yine kelimelerin geçmişten günümüze anlam ya da şekil bakımından geçirdiği değişimleri tespit etmek açısından da son derece önemli bir mevzudur (Türkben, 2018:216).

Çotuksöken (1989:11)'e göre bir dilin söz varlığı, 1. Tarihsel söz varlığı. 2. Kullanımdaki (güncel) söz varlığı şeklinde iki farklı yaklaşımla değerlendirilebilir. Tarihsel söz varlığı, dil birimlerinin art zamanlı tahlili iken güncel söz varlığı ise dil birimlerinin eş zamanlı (bugünkü) tespitidir.

Yaklaşık 12 milyon kilometrelik geniş bir coğrafyada 250 milyon civarında bir nüfus tarafından konuşulan ve köklü bir medeniyet dili olan Türkçe; mecaz, anlatım bolluğu, ağız çeşitliliği -Türkçenin ölçünlü yazı dilinde 65.00o civarında söz bulunmasına karşılık Anadolu ağızlarında bu sayının 80 100.000 civarında olduğu öngörülmektedir (Aksan, 2006:15).- kısa anlatımdan yana olmasına rağmen

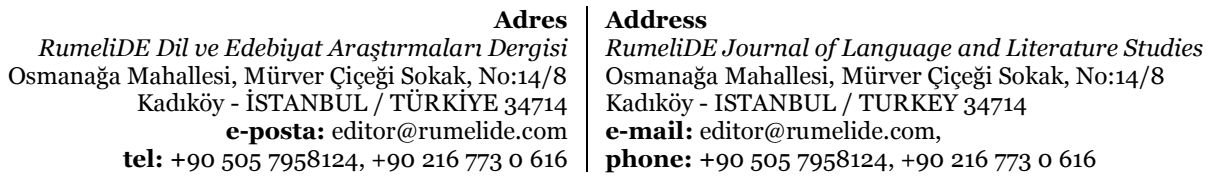


akrabalık adlarından renk, organ adlarına kadar zengin bir söz hazinesi ile dünyanın yaygın ve önemli dillerinden biridir (Yenen Avc1, 2014:121).

Türk dilini ve Türk kültürünü anlamak ve yorumlamak üzere yapılan araştırmaların merkezinde ise söz varlığı ile ilgili çalışmalar bulunmaktadır. Ülkemizde söz varlığı tespit çalışmaları konusunda oldukça zengin bir literatür (Akyalçın ve Aydoğan, 2019; Armut, 2018; Ayan ve Baş, 2015; Aytaç, 2018; Bulut, 2012; Çitgez, 2018; Daşman, 2017; Erol, 2007; Kahraman, 2017; Karababa, 2013; Karadeniz, 2018; Karagül ve Tarakc1, 2019; Lüle Mert, 2010; Sever ve Karagül, 2014; Soydan, 2018; Tosunoğlu ve Melanlığlu, 2005; Uçar, 2013; Uçar ve Adakll, 2019) bulunmaktadır. Bununla birlikte bugün söz varlığı ile ilgili yapılan çalışmalar arasında kelimenin kullanılma niceliği, frekansı manasındaki "kelime sıklığı" üzerine yapılan araştırmaların da sayısı ve önemi giderek artmaktadır. Dil eğitiminden okuduğunu anlama ve anladığını yazı ile ifade etmeye kadar pek çok mevzuda ortalama bir kelime bilgisi hayati bir unsur olarak görülmektedir. Yine kelime sıklığı çalışmalarının bahsedilen alanlarda olduğu kadar dilin iç yapısını ilgilendiren konularda da önemini vurgulamak gerekir. Nitekim kelimeler salt sözlükteki anlamlarıyla kullanılan dil unsurları değildir. Dilin değişken yapısına bağlı olarak zamanla çeşitli alanlarda ihtiyaç duyulan yeni durumları karşılamak üzere bazı kelimeler ya yeni anlamlar kazanır ya da başka kelimelerle birleşerek yeni bir form oluşturur. Kısacası dilin oldukça önemli mevzularından biri olan bu çok anlamlılık durumunun tespiti açısından da kelime sıklığı çalışmaları hayati önem arz etmektedir. Sözlükler incelendiğinde çok anlamlı unsurların genellikle kelime sıklığı fazla olan birimlerden oluşturulduğu söylenebilir. Yani kelimelerin kullanım siklı̆̆ arttıkça anlam alanlarının da genişleyerek çok anlamlılık kazandığı görülür. (Hirik, 2017: 57-58). Bu bakımdan anadili ya da yabancı dil öğretiminde Avrupa başta olmak üzere ülkemizde de sıklı çalışmaları ivme kazanmıştır. Ancak Batı'da yapılan çalışmalardan özellikle İngilizce ile ilgili olanlar ile Türkiye'de yapılan sıklık çalışmaları kıyaslandığında, Türkçe üzerine yapılan sıklık çalışmalarının yeterli düzeyde olmadığı söylenebilir.

Dünya literatüründe sıklıkla ilgili yapılan ilk çalışma, Thorndike tarafından 1944 yllında yayımlanan "The Teacher's Word Book of 3o.ooo" adlı eserdir. Semantik bir kelime sayımı niteliğinde olan ancak sıklıkla ilgili bilgilerin de aktarıldığı bu eser, ortaokul ve lise öğretmenlerine kaynak oluşturmak maksadıyla hazırlanmıştır. Coxhead tarafından 3,5 milyon kelimenin sıklığı ve aralığı incelenerek oluşturulmuş bir derlemden seçilmiş 570 kelime ailesini içeren "The Academic Word List" adlı eser de kelime sıklı̆̆ ile ilgili yapılmış önemli çalışmalardandır. Yine İngilizceyle ilgili kolejlerde kelime öğretimi için hazırlanan "Collage Vocabulary Skills"; anaokulundan sekizinci sinıfın sonuna kadar öğrencilere 1200 kelimeyi etkin olarak öğretmeyi hedefleyen "Elemantary Spelling Program" zikredilmeye değer eserlerdendir. Ayrıca İngilizce dışında İspanyolca, Fransızca, Portekizce ve Almanca gibi diğer diller için de pek çok sıklık çalışması yapılmıştır. Örneğin Almanca için en geniş kelime sayımı Keading ve Kühn tarafından yapılmıştır. Fransızca içinse 1953 yılında başlayan ve sözlü dili ele alan çalışmalar neticesinde 3500 kelimelik "Temel Fransızca" sözlüğü oluşturulmuştur (Akman, 2013:12-13-14).

Türkiye'de de sıklık üzerine yapılmış ilk denilebilecek çalışma, Amerikalı bilim adamı Mr. Birdge tarafından Yakup Kadri’nin Yaban romanı ile Reşat Nuri'nin Kızılcık Dalları ve Türk Tarih Kurumu'nun tarih kitabının I. ve II. cildi olmak üzere üç eserden 15.000 kelimenin sıklık listelerinin oluşturulduğu çalışmadır. Ömer Asım Aksoy ise 1936 yllında Birdge'nin listelerinden yararlanarak oluşturduğu kelime sıklık listelerini, Thorndike ve Hilliyer'in listeleri ile karşılaştırıp Türkçede sıklı̆̆a dayalı öğretilmesi en gerekli kelimeleri, "Bir Dili Öğrenmek için En Lüzumlu Kelimeler ve Bu Kelimelerin Belirtme Usulü” eserinde aktarmıştır (Akman, 2013:19-20). Türkiye'de kelime sıklığı ile

\begin{tabular}{r|l} 
Adres & Address \\
RumeliDE Dil ve Edebiyat Arasturmalart Dergisi & RumeliDE
\end{tabular} Osmanağa Mahallesi, Mürver Çiçeği Sokak, No:14/8 $\quad$ Osmanağa Mahallesi, Mürver Çiçeği Sokak, No:14/8 Kadıköy - İSTANBUL / TÜRKIYE 34714 Kadıköy - ISTANBUL / TURKEY 34714 e-posta: editor@rumelide.com e-mail: editor@rumelide.com, tel: +90 505 7958124, +90 2167730616 phone: +90 505 7958124, +90 2167730616 
ilgili yapılmış önemli bir diğer çalışma ise Pierce $(1961,1962)$ tarafından hazırlanmıştır. Pierce, \%75’i okuma yazma bilmeyen fabrika işçilerinin konuşmalarını bir berber dükkanında kaydederek oluşturduğu 47.0oo kelimelik havuza askerlik görevini yapmakta olan ve okuma yazma bilmeyen erlerin konuşmalarından derlediği 93.00o kelimeyi de ekleyerek 140.000 kelimelik bir sözlü derlem oluşturmuş ve bu verinin yazıya aktarılmasını sağlamıştır (Aksan ve Aksan, 2016:83).

Türkiye'de kelime sıklığı ile ilgili en kapsamlı denilebilecek çalışmalar, İlyas Göz ve Gökhan Ölker tarafından yapılmıştır. Göz, 1995-2000 yıllarının kelime sıklı̆̆ını tespit etmek maksadıyla dönemin basın, roman, hikâye, bilim, biyografi gibi daha pek çok farklı türdeki eserlerinden seçtiği metinlerden toplamda 975.141'lik bir kelime havuzu oluşturmuş; Ölker ise 1945-1950 arasında zikredilen pek çok farklı türdeki eserlerden 929.015 adetlik bir kelime havuzu oluşturmuştur (Çal, 2015:719).

Yukarıda zikredilen çalışmalar dışında da Türkçeyle ilgili birbirinden farklı alanlarda kelime sıklığı belirleme çalışmaları bulunmaktadır: ( Baş, 2011; Güzel ve Karadağ, 2013; Harmanda vd., 2011; Kılınç, 2020; Ulutaş ve Kara, 2020).

Ne var ki zikredilen çalışmaların büyük bir bölümü metin merkezli ya da art zamanlı söz varlığı araştırmaları şeklinde gerçekleştirilmiştir. Oysaki günümüzde bilhassa iletişim araçlarının durdurulamayacak bir hızla insan hayatına sunduğu imkânlar çerçevesinde artan küreselleşme olgusuyla da ekonomik, sosyal, kültürel alanlarda yaşanan pek çok olumlu gelişme, aynı oranda millî unsurları ve dilleri de olumsuz yönde etkilemeye başlamıştır. Nitekim Türk dili ve kültürü tarihinde de görüldüğü üzere geçmişte olduğu gibi günümüzde de kirlenme tehlikesi ile karşı karşıya kalan Türkçenin güncel ve önemli sorunlarından biri kitle iletişim araçlarında kullanımıdır (Demirtaş, 2019:338).

Sosyal ve kültürel alanlarda değişme ve gelişme pek tabii olmakla birlikte bu sürecin hangi şartlarda ve nasıl gerçekleştiği önemlidir. Günümüz dünyasında hemen her alanda değişimi gerektiren temel etkenleri şöyle sıralamak mümkündür:

\section{Kitle iletişim araçları,}

\section{Turizm sektörü,}

3. Yabancı dil eğitimi-öğretimi ve bu amaçla açılan kültür merkezleri,

4. Çevirifaaliyetleri,

5. İthalat ve ihracat faaliyetleri,

\section{Sanat dalları ve sanat elçileri.}

Bugünün dünyasında kişilerin ve ait oldukları toplumların hemen her konuda etkilendikleri araç, basın yayın organlarıdır. Bu organlardan ulaşılabilirlik bakımından en kolay ve ucuz olanı, hiç şüphesiz televizyondur. Modern çağda bireylerin nefes kesen bir hızla değişen yaşam koşullarına ayak uydurmak amacıyla televizyon özelinde dizi bağımlısı olduğu, güvenilir araştırma şirketlerinin televizyon-dizi vb. programların izlenme oranlarına dair yaptıkları araştırma neticelerinde de somut bir şekilde görülmektedir: Türkiye'de bireylerin günlük televizyon izleme ortalaması 6 saat iken,

\footnotetext{
Adres $\mid$ Address

RumeliDE Dil ve Edebiyat Araşttrmaları Dergisi $\quad$ RumeliDE Journal of Language and Literature Studies Osmanağa Mahallesi, Mürver Çiçeği Sokak, No:14/8 Osmanağa Mahallesi, Mürver Çiçeği Sokak, No:14/8 Kadıköy - İSTANBUL / TÜRKIYE 34714 Kadıköy - ISTANBUL / TURKEY 34714 e-posta: editor@rumelide.com e-mail: editor@rumelide.com, tel: +90 505 7958124, +90 2167730616 phone: +90 505 7958124, +90 2167730616
} 
araştırmaya katılanların \%84'ünün her gün televizyon izlediği ve \%67'sinin ise tercihinin özellikle yerli diziler olduğu belirlenmiştir (Bayram, 2018:57).

Kitle iletişim araçlarının ve özellikle televizyonun kültürel vb. değişimlerin en önemli platformu olması yanında milletlerin ölçünlü dilini, zaman zaman yanlış kullanımlarla kuşattığı ve bu yanlış kullanımların yayılma hızını ve alanını genişlettiği malumdur. Ekranlarda yapılan kişisel bir dil yanlışı çok kısa zamanda ve farkında dahi olunmadan topluma mal olmakta ve kitlesel bir dil yanlışına evrilerek dili kendi kurallarına aykırı bir değişime zorlamaktadır (Karahan, 1999:53). Hepçilingirler’in de belirttiği gibi televizyon icat oldu olalı zaten olmayan mertliğin hepten bozulduğu; televizyon kanallarının adlarından program adlarına kadar her şeyin giderek yabancılaştığı, ünlülerden siyasetçilere kadar kitlelere hitap eden camia tarafından ses-şekil, gramer bakımından yapay bir dil oluşturulduğu şu örneklerde somut bir şekilde görülmektedir: "Kendini birtakım negativilere itecek şeylerden uzak durmak lazım. / İnsanların başka yollarla da edinemedikleri başka kitaplarla ulaşabilirler. / İyi birine, güzel birine benziyorsanız beni mutlu ediyor yani sonuçta. / Daha önce senin gibi sudan bir nedenle iş yemeğini kimse bozmamıştı. / Bu aylıklarla doğadaki otlardan toplayarak lezzetli yemekler yapabiliyorsanız gül gibi geçinip gidersiniz." (Hepçilingirler, 2005:97-105).

\section{Yöntem}

\section{Araştırmanın modeli}

Kitle iletişim araçlarından televizyonda dünden bugüne yayınlanan dizilerin adlarını, Türkçenin söz varlığı bakımından deşifre etmeye yönelik hazırlanan bu çalışma, hem örnek durum çalışması hem de tarama modellerinde tasarlandığı için karma yöntemle oluşturulmuştur. Örnek durum çalışması, tek bir konu için arşiv niteliğinde belge olarak ya da belirli bir durumla ilgili sonuçlar ortaya koymak için birkaç başka durumun derinlemesine incelenmesi şeklinde tanımlanabilir. Tarama araştırması ise "ne, nasll, ne kadar, nerede" gibi sorulara cevaplar arar (Wellington, 2006: 31-32). Bu araştırmada da Türkçenin söz varlığı bakımından durumu, dizi adları aracılı̆̆ıyla tespit edilmiş ve ulaşılan veriler, tarama yöntemindeki sorular ışığında yeniden değerlendirilmiştir. Araştırma süreci Şekil 1'deki gibi gerçekleşmiştir:

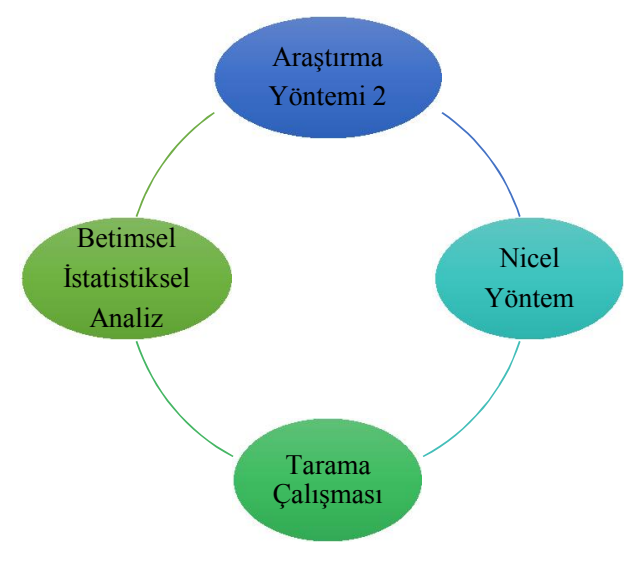

Şekil 1. Araştırmanın aşama diyagramı

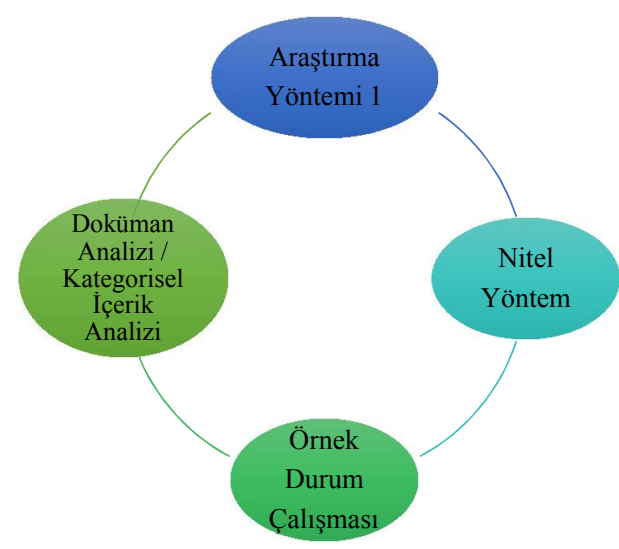

Adres

RumeliDE Dil ve Edebiyat Araştırmaları Dergisi Osmanağa Mahallesi, Mürver Çiçeği Sokak, No:14/8 Kadıköy - ISTANBUL / TÜRKIYE 34714 e-posta: editor@rumelide.com tel: +90 $5057958124,+902167730616$
Address

RumeliDE Journal of Language and Literature Studies

Osmanağa Mahallesi, Mürver Çiçeği Sokak, No:14/8

Kadıköy - ISTANBUL / TURKEY 34714

e-mail: editor@rumelide.com,

phone: +90 505 7958124, +90 2167730616 
Günümüzde kitle iletişim araçlarından televizyonun pek çok bireyin hayatının merkezinde olmasına bağlı olarak konunun hem kullanılan dilin durumu hem de kültürel değerlerin işleniş şeklinin çözümlenmesi açısından yapılan sayısız çalışma bulunmaktadır (Akınerdem, 2012; Güzel ve Karakurt, 2016; Kurtdaş, 2018; Türker ve Kırık, 2019; Yalçı, 2016; Yılmaz, 2020). Ancak dünyanın pek çok yerinde olduğu gibi Türkiye'de de popüler kültürün birinci dereceden aktarıcısı konumunda olan dizi film adlarında dilin kullanımını irdeleyen çalışmalar sınırlı düzeydedir (Yılmaz ve Özkurt, 2016). Dolayısıyla bu araştırmadaki temel amaç, televizyon dizi adlarını Türkçenin söz varlığı bakımından değerlendirmek ve Türkçedeki kelime türlerinin dizi adlarında kullanım sıklıklarını, kullanım formlarını tespit etmektir. Söz varlığı tespit çalışmalarının, dilin zenginleşmesine ve gelişmesine katkı sunması yanında dilin o günkü durumunun analizi açısından da son derece önemli olduğunu vurgulamak gerekir (Türkben, 2018).

\section{Verilerin toplanması ve çözümlenmesi}

Karma yöntemle hazırlanan bu araştırmada genel reyting değerlendirmelerine (https://tiak.com.tr/tablolar\#aylik-tablolar, Erişim Tarihi:01.03.2020) göre izlenme sıralamasında önde olan ATV, Fox, Kanal D, Show, Star ve TRT 1'e ait toplam 576 dizi adı doküman analizi ile değerlendirilmiştir. Araştırma için kanalların ilgili internet sitelerinden derlenen bu dizi adlarındaki anlamlı ya da görevli her bir kelime kategorisel içerik analizi ile Zeynep Korkmaz'nn (2009) Türkiye Türkçesi Grameri-Şekil Bilgisi eserindeki tasnife uygun bir şekilde fişlenmiştir. Fişlenen kelimeler; anlamlı kelimeler (adlar, sıfatlar, zamirler, zarflar, fiiller), görevli kelimeler (bağlaçlar, edatlar) ve anlamlı-görevli kelimeler (ünlemler) şeklinde kategorize edilmiştir. Kelimelerin hangi kanala ve diziye ait olduğunu belirlemek için televizyon kanalları ve her kanala ait dizi adları da kendi içinde alfabetik bir şekilde sıralanmış; dizi adlarındaki her kelime, parantez içinde ait olduğu kanalın sıra numarası ve dizinin sıra numarası ile birlikte verilmiştir. Böylelikle tarama modeline uygun bir yöntemle hangi kanalda ne türden kelime kullanıldığı ile ilgili verilerden yola çıkarak istatistiksel grafikler oluşturulmuştur. Ayrıca anlamlı kelimeler bölümünde, adlardan ve fiillerden sonra bu kategorilerde birden fazla kullanılan kelimelerin sıklık tabloları oluşturulmuş; görevli ve anlamlı-görevli kelimeler bölümünden sonra da yine bu kategorilerde kullanılan kelimelerin sıklık tabloları verilmiştir. "Ekler-1" bölümde ise dizi adlarındaki kelimelerin istatistiksel tablo ve grafikleri aktarılmış; "Ekler-2" bölümünde de ilgili kanallara ait dizi adları listelenmiştir.

\section{Bulgular}

Günümüzde bireylerin hemen her konuda sınırsız bir etkileşim yaşadığı araç televizyondur. Diğer ülkelerde olduğu gibi Türkiye'de de televizyonun gündem oluşturma ve yönlendirme noktasında etkilerinin fazlasıyla hissedildiği konu dil kullanımıdır (Güllüdağ, 2012:50). Dolayısıyla televizyonun Türk toplumunun hayatında merkezi bir konumda olmasına bağlı olarak bu platformda kullanılan dilin hem kendi kuralları hem de kültür taşıyıcılığı rolü açısından mutlaka sorgulanması gerekmektedir. $\mathrm{Bu}$ maksatla söz konusu çalışmada yaygın olarak izlenen 7 televizyon kanalında yayınlanan toplam 576 dizi adının söz varlığı aşağıdaki gibi kelime türleri ve kullanım sıklıkları bakımından incelenmiş ve sözlük düzeninde verilmiştir. Söz konusu televizyon kanallarının internet sitelerinden derlenen 576 dizi adından 1096 adet anlamlı kelime, 28 adet görevli kelime ve 7 adet de anlamlı-görevli kelime olmak üzere toplam 1131 adet kelime tespit edilmiştir. Bu kelimeler, bağlamdaki fonksiyonları dikkate alınarak tür bakımından tasniflenmiş; tasnifler esnasında her kelime, kanalların alfabetik sıra numarasına ve ait olduğu kanaldaki kendi alfabetik sıra numarasına göre kodlanarak verilmiştir. (7/25: TRT'deki 25 numaraları diziye ait kelime şeklinde.) Böylelikle her 
kategoride toplanan kelimelerin kodlardan yola çlkarak hangi kanaldaki hangi diziye ait olduğu tespit edilerek ulaşılan sayısal verilerle çeşitli grafikler oluşturulmuştur. Ayrıca her kategorideki kelimelerin sıklıkları da tablolar halinde aktarılmıştır:

\subsection{Anlamlı kelimeler}

\subsubsection{Adlar ve ad soylu kelimeler}

\subsubsection{Adlar}

\subsection{Ortak adlar}

Dizi adlarında \%70'lik bir oranla ilk sırada ortak adların yer alması; kültür, çağrışım ve muhakeme gücüne dikkat çekme durumunda özellikle adlardan faydalanıldığı tezini destekler niteliktedir (Bulak, 2016: 284). Nitekim kullanım sıklığı bakımından oldukça fazla olan ortak adlardan anne, baba, bebek, çocuk, damat, gelin, kadın, kardeş, kız, oğlan gibi aynı kavram alanında olan aile/akrabalık adları bu tezi örneklendirmektedir. Bu durum, ailenin ve aile ilişkilerinin önemli olduğu Türk kültürüne uygunluk göstermesi yanında Türk dilinin aile/akrabalık adları bakımından diğer dünya dillerine göre çok daha zengin olduğunu da ispatlar niteliktedir. Yine dizi adlarında sıklıkla tercih edilen aşk, sevda, sevgili, umut, yalan gibi duygusal durum ifadesi olan soyut adlardan yola çıkarak Türk milletinin manevî duygulara önem veren bir toplum olduğunu söylemek mümkündür.

1 (1/41), 309 (2/70), 4n1k (2/1), abur cubur (7/2), ad (2/2, 2/3, 3/1, 3/14, 5/5, 7/4), adam (7/79), ağaç $(1 / 58,7 / 38)$, aile $(1 / 5,1 / 26,2 / 15,2 / 59,3 / 12,3 / 33,4 / 11,6 / 3,6 / 42)$, akasya $(3 / 2,6 / 4)$, alın yazisı (3/3), analı oğullu (3/5, 5/9), anne $(1 / 8,3 / 8,4 / 276 / 5,6 / 6,6 / 19,6 / 86$,), araf (2/5), arkadaş (3/97, 5/10, 6/96), art (1/61), asayiş (2/7), aşk (1/10, 1/11, 1/12, 1/34, 2/1, 2/8, 2/9, 2/10, 2/16, 2/46, 2/47 2/88, 3/7, 3/10, 3/11, 3/17, 3/40, 3/79, 3/92, 4/8, 4/9, 4/42, 5/1, 5/2, 5/12, 5/13, 5/14, 5/52, 6/7, 6/8, $6 / 66,6 / 71,7 / 8,7 / 13,7 / 33,7 / 85)$, ateş $(3 / 52,6 / 9,6 / 74)$, avcı $(1 / 65)$, avlu (6/11), ay (6/12), ayna (2/75), ayrllı (7/11), ayrım (7/84), azap (1/14), baba (1/15, 1/70, 2/11, 2/12, 3/12, 5/21, 6/14, 6/15, 6/16, 7/12), bahar (1/44, 6/94), bahçe (3/78), baldız (1/17), balık (6/88), başkan (7/87), başrol (7/13), bebek $(1 / 16,5 / 16)$, bedel $(2 / 74,4 / 32,6 / 7)$, berkemal (2/7), beş (7/39), beyaz (2/58), biçak sirtı $(4 / 7)$, birader (2/69), boynu bükük (3/23), böcek (6/9), börü (6/26), bugün (1/23), bulut $(3 / 16,7 / 19)$, can (1/26, 2/23, 4/11, 5/21, 6/27, 7/12), canevi (1/25), cam (7/21), cennet (1/27,6/28), cesur (6/29), cihan (3/69), cinayet $(3 / 24,6 / 92)$, çakıl (2/24), çember (6/30), çıkış $(7 / 69)$, çiçek $(1 / 28,1 / 51)$, çift $(3 / 73)$, çiftlik (3/39), çilek (6/31), çirkin (3/38), çoban yıldızı (2/26), çocuk $(1 / 27,2 / 27,3 / 17,3 / 27,6 / 23$, 6/32, 6/55, 6/64, 7/31), çocukluk (7/24), çukur (5/24), damat (4/40, 6/90), dans (5/6), dede (2/29), dedik (2/54), defter (2/71), deli (7/44), deli divane (4/12), delikanlı (5/51), deniz (3/18, 7/83), deniz kızı (6/33), deniz yıldızı (2/31, 5/26), destan ( $7 / 70)$, devir $(2 / 63,5 / 54)$, devriye (7/54), doktor $(2 / 34$, $2 / 66,4 / 14)$, dolap (2/29), dolunay (6/35), dost (2/49, 3/28), dudak (5/28), durak $(3 / 2,6 / 4)$, durum (5/43, 5/44), duvar (1/31), düğün $(5 / 15)$, dükkan $(5 / 55)$, dünya $(1 / 33,3 / 94)$, düş $(2 / 35)$, düşman (5/77, $7 / 10)$, efendi (4/31), ekmek (4/16, 5/13), el (1/32), el (7/26), elma (2/87, 7/47), emanet $(2 / 36)$, erkek (6/24), esaret (2/37), eşkiya (1/33), ev (1/15, 1/22, 2/85, 3/87, 5/32, 6/38), evlat (3/29, 6/16), evli (5/43), fabrika (5/35), familya (2/38), fatih (3/69), feda (4/17), firtına $(2 / 56,6 / 52)$, firar $(6 / 40)$, gebe (3/41), gece (6/41), gece gündüz (3/32), geçmiş $(6 / 84)$, gelin $(5 / 75,6 / 56,6 / 59)$, gelincik $(1 / 19)$, gemi (1/66), göç (6/43), gökkuşağ 1 (7/31), gönül $(2 / 30,5 / 39,6 / 44,7 / 32)$, görgüsüz $(1 / 38)$, gözyaş1 (3/19), gurbet (7/33), gurur (5/14), gügüum (6/36), gül (1/76, 3/35), gün $(2 / 41,5 / 42,6 / 60,7 / 24)$, günah $(3 / 11,6 / 15)$, günahkâr $(2 / 42)$, güneş $(3 / 36)$, güvercin $(6 / 45)$, güzel $(2 / 44,3 / 38,6 / 29)$, hal

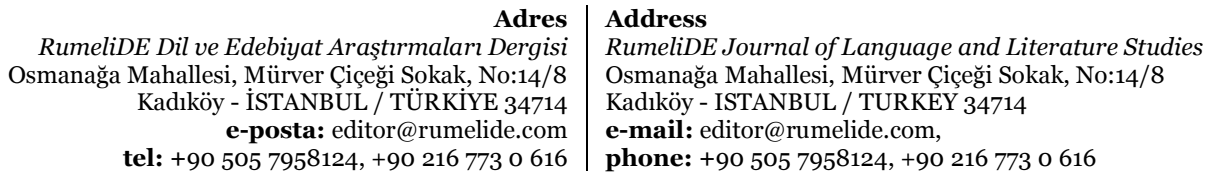


(1/22, 2/10), halka (7/35), hanım (6/47), harem (2/43), hatıra (4/24), hayal (1/40,5/13), hayat (2/44, 2/65, 2/72, 3/41, 3/43, 4/1, 4/18, 4/26, 5/37, 6/49, 6/50, 7/26, 7/38, 7/80), hercai (1/42), hesap (6/71), hiçkırık (3/44), hırsız (7/32), hicran (7/42), hikâye (2/15, 2/16, 2/18, 2/20, 3/17, 6/1, 7/29, 7/30), hoca (1/3), ışık (6/12), ibreti alem (6/51), iç (6/27), içeri (5/45), iffet (6/53), ihanet (6/54), ikili (3/72), ikizler (3/46), ilişki $(5 / 43,5 / 44)$, inci $(6 / 87,7 / 63)$, insanlı (3/48), intikam (3/49,3/83), isimsiz (3/50), isyan (7/7), iş (5/16, 6/44), işgal (4/25), işler güçler (6/57), iyi (5/10), kaçak (1/45), kadın (2/41, 2/48, 2/85, 3/65, 3/87, 6/24, 6/72), kahraman (5/48), kalp (2/51, 2/76, 3/53, 4/3, 4/7, 5/28, 5/47, 6/61, 6/62, 7/6, 7/56), kanal (7/23), kanat (7/67), kanit (3/51,3/52), kanun (7/8, 7/50), karagül (2/53), karakol (5/50), kardeş (3/15, 5/29, 6/64, 6/65), karı (2/54), karışık (5/44), kayıp (3/56, 7/46), kayıtdışı (2/55), kelebek (1/49, 1/51, 7/55), kırık (7/21), kırlangıç (2/56), kırmızı (6/67), kıyı (4/18), kız (2/90, 3/37, 3/59, 4/27, 5/35, 6/6, 6/39, 6/81, 7/86), kiraz (2/57), klavye (5/51), kobra (4/28), koca (2/59), koku (3/29, 6/31), komşu (2/60), konak (1/9), kontrbas (2/54), korkusuz (1/55), kördüğüm (2/61, 4/29), köy (7/44), köylü (6/46, 6/47), kraliçe (5/56, 6/41), kurşun (2/62), kurt (3/62, 4/30, 5/53, 6/69, 7/50), kuş (1/46, 5,67,6/37, 7/67), kuş dili (1/57), kutu (3/54), kuzgun (6/70), kül (6/74), küstüm çiçeği (7/52), lale (2/63, 5/54), leke (3/67), limon (1/58), lira (4/33), lise (7/54), litre (3/19), mahalle (1/59, 3/28), mahşer (1/60), makber (6/75), mal (5/73), mantı (7/1), masal $(1 / 21,3 / 22,4 / 36,7 / 16)$, masum (3/68), mayıs (5/56), mazi $(7 / 56)$, medcezir $(6 / 76)$, melek $(2 / 64,2 / 81,5 / 58,6 / 19)$, menekşe (7/59), merhaba (2/65), merhamet (3/70), mesele (3/81), mevsim (2/57, 6/61), mihrap (5/57), milat (7/58), mucize (2/19, 3/41), muhtar (1/59), mutluluk (2/2), müezzin (7/3), münasebet (5/60), müzik (4/31), no (2/70), not (2/71), nöbet (5/61), ocak (6/14), oğlan (2/90, 7/86), oyun (1/10), ömür $(2 / 74,4 / 32,6 / 25)$, öte (7/19), öykü (3/95), papatya (6/79), paramparça (6/80), parmaklık (1/61), pay (6/65), prens (7/61), pusu (3/62, 5/53,6/69), reis $(6 / 3)$, ruh $(2 / 75)$, rüzgar $(2 / 17,2 / 76)$, saadet $(1 / 5,2 / 25)$, saat $(1 / 67,7 / 40,7 / 64)$, saray $(6 / 82,7 / 63)$, sarayl $(1 / 23,5 / 25)$, sarmaşı $(2 / 89)$, savaş (3/35), savaşçı (2/78), sebep (7/71), seksenler (7/65), serçe (6/82), servet $(1 / 65,5 / 68)$, servis (5/4), sevda $(4 / 36,5 / 20,6 / 63,7 / 67)$, sevdaluk (5/70), sevgili $(1 / 39$, $2 / 33,6 / 48,6 / 84)$, sinif $(5 / 71,7 / 68)$, sir $(3 / 66,6 / 28,6 / 50,6 / 73)$, siradaki (2/6) sirat (6/85), sofra (7/34), sokak (5/46), sonbahar (6/89), sonsuz (4/39), soy (3/4), sosyete $(6 / 58,6 / 97)$, su $(2 / 32,6 / 88)$, suç (3/31, 3/48), sultan (6/62), suskun (5/72), sürgün (1/12, 7/20), şahit (6/95), şarkı (3/43,7/61), şehir (2/81, 3/57), şeref (3/81), şöhret (1/72), şubat (7/73), şüphe (3/82), tacir $(7 / 74)$, takip $(4 / 28)$, taksi (1/28), talih kuşu (1/73), taş (2/24), tatlı (6/49), tekne (4/16), tepe (3/99), teşekkür $(5 / 62)$, tiyatro (1/20), tokat (7/60), tutam (4/9), tutsak (3/84), umut (2/6, 2/14, 2/35, 2/84, 3/20, 6/20), üst (3/52), vadi $(3 / 62,4 / 30,5 / 53,6 / 69)$, var $(2 / 14,6 / 20,7 / 26)$, vatan $(3 / 90,5 / 65)$, veda $(3 / 91)$, vicdan (3/93), vurgun (2/86), yaban (1/76), yabanc1 (1/43, 4/23), yalan (1/24, 2/8, 3/60, 4/10, 5/19, 6/21), yalancı $(1 / 77,3 / 45,3 / 94,6 / 91)$, yalaza $(7 / 76)$, yaka (1/13), yangin $(2 / 51)$, yara $(7 / 42,7 / 56)$, yastık (7/15), yaş (2/24), yazı (3/55), yazmalı (1/7), yedili (5/66), yemin (4/41), yenge (3/21), yer (2/45, 2/51, 4/22, 5/57, 7/82), yer gök (2/88, 4/42), yersiz yurtsuz (1/78), yll (3/96), ylldı (6/95), yoksul (1/79), yokuş (7/80), yol $(1 / 14,3 / 61,3 / 97,4 / 43,5 / 30,6 / 96,7 / 84)$, yolculuk (7/85), yuva (2/82), yüksek (7/82), yürek (1/29, 2/28, 4/13, 5/22, 7/75), yüz (5/78), yüzyıl $(2 / 67,5 / 59,6 / 77,7 / 27)$, zaman $(2 / 5$, $3 / 76,6 / 43,7 / 30)$, zemheri (5/79), zengin (1/79), zeytin (3/99).

\subsubsection{2. Özel adlar}

\subsection{Kişi adları}

Televizyon dizi adlarında toplamda 82 adet kişi adı tespit edilmiştir. Bu adların yarısı kadın adları iken diğer yarısı da erkek adlarıdır. Kadın ve erkeğin toplum hayatındaki eşit pozisyonu, dizi adlarında da her iki cinsin eşit yer almasıyla paralellik içermektedir.

\footnotetext{
\begin{tabular}{r|l} 
Adres & Address \\
RumeliDE Dil ve Edebiyat Araşttrmalar Dergisi & RumeliDE Journal of Language and Literature Studies
\end{tabular} Osmanağa Mahallesi, Mürver Çiçeği Sokak, No:14/8 Osmanağa Mahallesi, Mürver Çiçeği Sokak, No:14/8 Kadıköy - İSTANBUL / TÜRKIYE 34714 Kadıköy - ISTANBUL / TURKEY 34714 e-posta: editor@rumelide.com e-mail: editor@rumelide.com, tel: +90 505 7958124, +90 2167730616 phone: +90 505 7958124, +90 2167730616
} 
Ahmet (7/77), Ali (2/4), Aliye (1/6, 4/5), Ayşe (2/4), Bayram Bayram (7/4), Behzat Ç. (6/17), Can (3/46), Canan (2/22), Cevdet (7/40), Cuma (3/25), Deniz (2/52, 3/18), Dila (5/27,6/34), Düriye (6/36), Emir (5/30), Efsane (3/1), Elif (4/15), Ertuğrul (7/25), Ezel (1/35, 5/33), Ezra (5/34), Fatih (3/30), Fatmagül (3/31), Fazilet (6/39), Ferhat (2/18, 2/40), Feriha $(4 / 2,5 / 3)$, Firuze (5/36), Gazi (1/36), Gerçek (1/40), Gülizar (3/34), Güneş (3/37), Güney (3/63), Gülperi (5/40), Halil İbrahim (7/34), Hayal (1/40), Hayati (3/42), Hicran (3/13, 7/42), Iffet (6/53), Karayel (3/77), Kemal (2/73, 5/74), Kösem (2/67), Kuzey (3/63), Leyla (7/53), Mavi (1/11), Mecnun (7/53), Mehmed (3/69), Memo (3/46), Meryem (3/71, 4/19), Neriman (5/7), Nevzat (1/54), Nuri (3/75), Osman (1/56), Ömer (4/20), Poyraz (3/77), Ramazan (1/74), Rex (7/48), Salih (5/67), Selena (1/62), Sevda (3/78), Seyit (6/68), Sıla (1/68, 4/38), Sultan (3/80), Şevkat Yerimdar (2/83), Şirin (2/18, 2/40), Şura (6/68), Türkan (3/85), Yaz (3/95), Yunus Emre (7/85), Yusuf (4/21, 7/16), Zehra (2/3), Zerda (1/80, 4/44).

\subsection{Lakaplar}

Dizi adlarında tespit edilen lakapların tamamı erkekler için kullanılmıştır. Bu durum, Türk toplumunda lakap verme konusunda kadının mahremiyeti ve kutsiyeti ile izah edilebilir.

Adanalı (1/1), Altın dağlı (5/8), Heredot (7/40), Karadağlar (5/49), Karadayı (1/47), Karayılan (1/48), Kertenkele (1/50), Kurt (6/68), Tatar (1/74), Urfalı (3/88, 6/93), Ustura (5/74).

\subsection{Unvanlar}

Dizi adlarında toplumdaki hitap şekillerini gösteren unvanlara yer verilmekle birlikte sayıları sınırlı düzeydedir. Bu unvanlar genellikle toplumdaki konuma ve mesleğe bağlı verilen adlardır.

Ağa (3/64), hanım (3/39, 5/27, 6/34, 6/39), hanımefendi (7/51), hazreti (4/19 4/20, 4/21), komiser (1/54, 7/48), mehmetçik (7/57), öğretmen (2/73), sefir (6/81), sultan (7/28), yamak (7/77).

\subsection{Millet, devlet, topluluk, boy ve aşiret adları}

Dizi adlarında bu kategoriden sadece “Osmanlı ve Türk” adları TRT 1 ve Show TV'de tespit edilmiştir.

Osmanlı (7/17, 7/60), Türk (5/73).

\subsection{Kıt'a, ülke, yer, şehir, ırmak vb. adları}

Dizi adlarında tespit edilen 29 adet yer adının 22 adedi, ülke sınırları içinde yer alan coğrafya adlarıdır. Kullanım sıklı̆ı en fazla olan yer adı ise uzun yıllar Osmanlı Devleti’ne başkentlik eden İstanbul'dur. O dönemlerde yönetimin ve buna bağlı olarak aydın kesimin de İstanbul'da olması gibi sebeplerle kent ön plana çlkmıştır ve hem o dönemlerde hem de sonraki dönemlerde bilimsel, sanatsal etkinliklere ev sahipliği yapmıştır. Dolayısıyla ekonomik hareketliliklerin de merkezinde olan kent, sosyal anlamda toplumun farklı kesimlerindeki kalabalık insan gruplarına yaşanılası bir coğrafya olmuştur. İstanbul'daki bu değişik ve renkli yaşam şekilleri dizilerde sık sık işlenen konular olarak karşımıza çıkmaktadır.

Ankara (3/6), Avrupa (1/13), Avrupa Avrupa (7/9), Balkan (5/15), Bodrum (3/22), Dicle (1/30), Dikmen (3/6), Ege (3/53), Es Es (5/31), Firat (7/62), Gültepe (3/14), Hanımeli Sokağı (7/37), Hindistan (2/46), İstanbul (1/4, 1/21, 3/86, 4/24, 5/46, 6/55, 7/22, 7/43), Kafkasya (7/20), Karadeniz

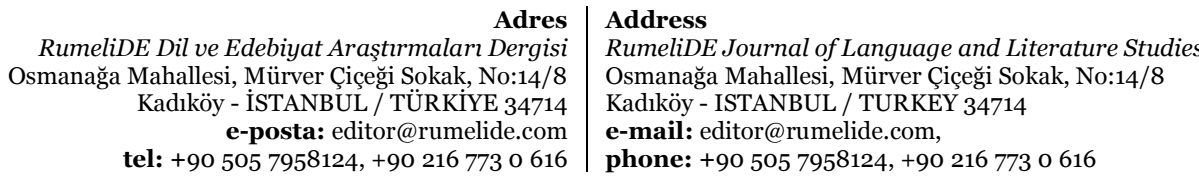


(1/63), Kut'ül Amare (7/57), Sakarya (7/62), Seddülbahir (7/64), Şahin Tepesi (1/71), Üsküdar (3/89), Yedikule (7/80).

\subsection{Kurum, kuruluş, dernek, okul, otel vb. adları}

Dizi adlarında; kurum, kuruluş, okul vb. adlardan sadece iki adet otel adı tespit edilmiştir.

Kahireli Palas (2/50), Otel Divane (5/63).

\subsection{Astronomi ile ilgili adlar}

Dizi adlarında gök ya da gök cisimleriyle ilgili bir adet yıldız adı, Show TV'den tespit edilmiştir.

Kuzey Yıldızı (5/52).

\subsection{Gazete, dergi, kitap, roman vb. adları}

Dizi adlarında bu kategoriden tespit edilen adların tamamı, Türk edebiyatının önemli eserleri olan roman adlarından oluşmaktadır. Neredeyse her kanalda romandan uyarlanmış dizilerin yer aldığı görülmüştür.

Aşk-ı Memnu (3/9), Çalıkuşu (3/26), Fatih Harbiye (2/39), Gece Sesleri (5/38), Keşanlı Ali Destanı (3/58), Nefes Nefese (6/78), Sinekli Bakkal (1/69), Yedi Güzel Adam (7/79), Yılanların Öcü (5/76).

\subsection{9. Şarkı, türkü vb. adları}

Kültürel unsurların önemli bir parçası olan şarkı, türkü adlarının tamamı, TRT 1 kanalına ait dizilerden tespit edilmiştir.

Aşkın Kanunu (7/8), Hangimiz Sevmedik (7/36), Sevda Kuşun Kanadında (7/67).

Grafik 1: TV dizi adlarında ad türündeki kelimelerin kanallara göre oransal dağılımı

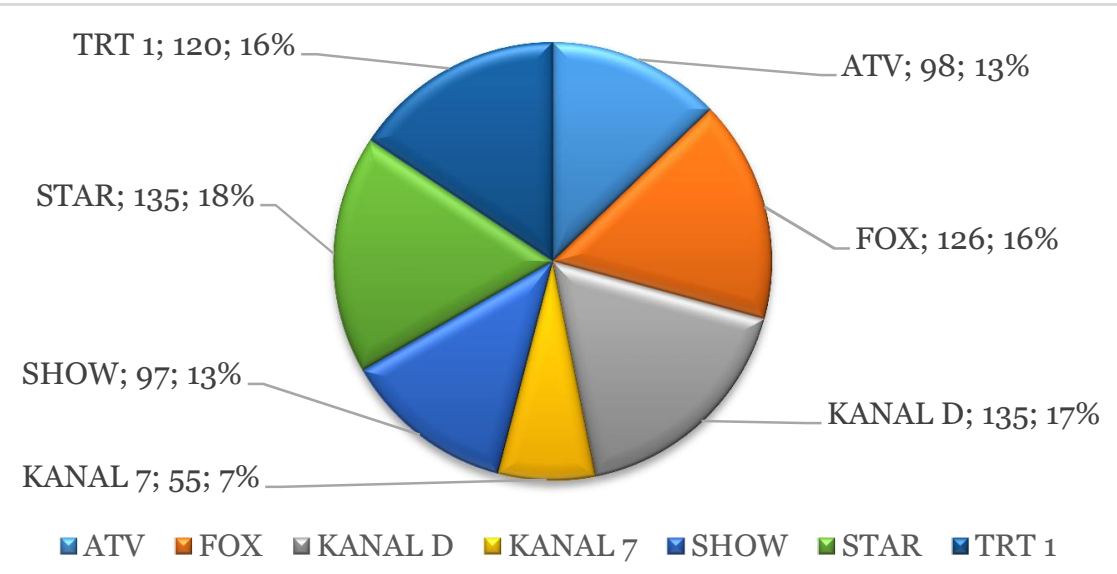

Grafik 1'de dizi adlarında tespit edilen toplam 770 adet ad türündeki kelimenin kanallardaki oransal dağılımı verilmiştir. Grafik incelendiğinde dizi adlarında ad türündeki kelimelerin en fazla Star'da, en az ise Kanal 7’de kullanıldığı görülmektedir.

\begin{tabular}{r|l} 
Adres & Address \\
RumeliDE Dil ve Edebiyat Araştırmalarn Dergisi & RumeliDE Journal of Language and Literature Studies \\
Osmanağa Mahallesi, Mürver Çiçeği Sokak, No:14/8 & Osmanağa Mahallesi, Mürver Çiçeği Sokak, No:14/8 \\
Kadıköy - İSTANBUL / TÜRKIYE 34714 & Kadıköy - ISTANBUL / TURKEY 34714 \\
e-posta: editor@rumelide.com & e-mail: editor@rumelide.com, \\
tel: +90 505 7958124, +90 216 773 0 616 & phone: +90 505 7958124, +90 2167730616
\end{tabular}




\subsubsection{Sifatlar}

Dizi adlarından yola çıkarak Türkiye'de yayınlanan dizilerin çoğunun bir şahsın, bir grubun; toplumun bir kesiminin hayatından kesitler sunduğunu ve güncel yaşam şekillerini ekranlara taşıdığını söylemek mümkündür. Dolayısıyla bu amaca uygun bir şekilde ayrıntılara dikkat çekmek üzere dizi adlarında kullanım sıklığı bakımından ikinci sırada sıfatlardan, özellikle de niteleme sıfatlarından faydalanılmıştır (Coşkun, 2010:78).

\subsection{Niteleme sıfatları}

Dizi adlarında tespit edilen sıfatların büyük çoğunluğu niteleme türünde kullanılan sıfatlardır. Hemen her kanaldaki dizi adlarında niteleme türünde birçok sıfatın kullanıldığı görülmüştür.

Acayip (6/1), acemi (7/3), acı (4/1, 5/1), acil (5/2, 5/4), al (1/7), altın (3/4), arka (2/6), asmalı (1/9), aynadaki (7/10), belalı (1/17), beyaz (1/19, 5/19), bir (7/15), büyük $(1 / 24,4 / 10,7 / 20)$, cesur $(5 / 22)$, çlgın (7/23), çifte $(2 / 25)$, deli $(1 / 29,2 / 17,2 / 30,4 / 13,5 / 20,5 / 25)$, demet (1/20), derin $(2 / 32)$, düşman (5/29), erkenci (6/37), esir (7/28), eski (7/29), evvel (7/30), fakir (2/90, 7/86), gamsız (5/37), garip (4/8), geniş $(3 / 33,6 / 42)$, güzel $(6 / 46,7 / 79)$, içimdeki $(6 / 52)$, ilk $(2 / 1,5 / 52)$, İstanbullu $(6 / 56)$, jet (6/58), kaçak (6/59), kadim (2/49), kalbimdeki (2/52), kanatsız (1/46), kara (3/54, 3/55, 6/63), karşı (7/44), kayıp (3/57), 4/26), kırgın (1/50), kızıl (7/47), kiralık (6/66), kirli (2/58), koca koca (3/60), koyu (6/67), kötü (3/61), küçük (3/64, 3/65, 3/66, 6/71, 6/72, 6/73, 6/91, 7/51), manyak (5/55), mavi (7/55), mor (7/59), mucize (2/66), muhteşem (2/67, 3/72, 5/59,6/77), mükemmel (3/73), pis (5/66), sarı sarı (4/33), sessiz (1/66), sicak (1/67), sihirli (6/86), siyah (6/87), siyah beyaz (3/79), son (7/69, 7/70), sudan (7/71), süper (1/70), şahane (6/90), şen $(2 / 82)$, tatlı $(3 / 83,6 / 21$, 6/91), tek (7/75), ufak tefek (6/92), umutsuz (2/85, 3/87), uzun (7/27), yabancı (4/40), yalan (3/94), yalancı (6/94), yasak (2/87), yeni (5/75), yeşil (7/83), yuvamdaki (5/77), yüksek (6/97), zehirli (2/89), zengin $(2 / 90,7 / 86)$, zoraki $(7 / 87)$.

\subsection{Belirtme sıfatları}

Türkiye'de yayınlanan dizilerin pek çoğunun gündelik yaşamdan ve belli bir kişinin, kesimin hayatlarından kesitler sunduğu düşünüldüğünde dizi adlarında belirsizlik sıfatlarından ziyade işaret ve sayı sıfatlarının kullanılması olağan görünmektedir.

\subsection{1. İşaret sıfatları}

Dizi adlarında işaret sıfatlarından sadece $\boldsymbol{o}$ sıfatı Fox TV'de yer alan bir dizi adında tespit edilmiştir.

$\mathrm{O}(2 / 72)$

\subsection{Sayı sıfatları}

Dizi adlarında tespit edilen 8 farklı sayı sıfatından kullanım sıklığı en fazla olan bir sıfatıdır.

32 (7/64), 6 (7/1), beş (3/15), bir (1/20, 1/21, 2/77, 3/18, 3/19, 3/20, 3/69, 4/8, 4/9, 6/19, 6/24, 6/25, 7/16), dört (6/61), iki (1/43, 3/45, 4/23), ikinci (1/44), yedi (7/79).

\begin{tabular}{|c|c|}
\hline & \\
\hline debiyat & Studie \\
\hline $\mathrm{Mah}$ & Mahallesi, Mürver Çiçeği Sokak, No:14/8 \\
\hline Kadıköy - İ & STANBUL / TURKEY 34714 \\
\hline $\begin{array}{r}\text { e-posta: editor@rumelide.com } \\
\text { tel: }+905057958124,+902167730616\end{array}$ & $\begin{array}{l}\text { e-mail: editor@rumelide.com, } \\
\text { phone: +90 505 7958124, +90 } 2167730616\end{array}$ \\
\hline
\end{tabular}




\subsection{Belirsizlik sıfatı}

Dizi adlarında yalnızca iki kelime, belirsizlik sıfatı türünde kullanılmıştır.

$\operatorname{Bir}(2 / 15,2 / 16,2 / 17,2 / 18,2 / 19,3 / 16,3 / 17,5 / 20,6 / 19,6 / 23)$, her (2/45).

Grafik 2: TV dizi adlarında sıfat türündeki kelimelerin kanallara göre oransal dağılımı

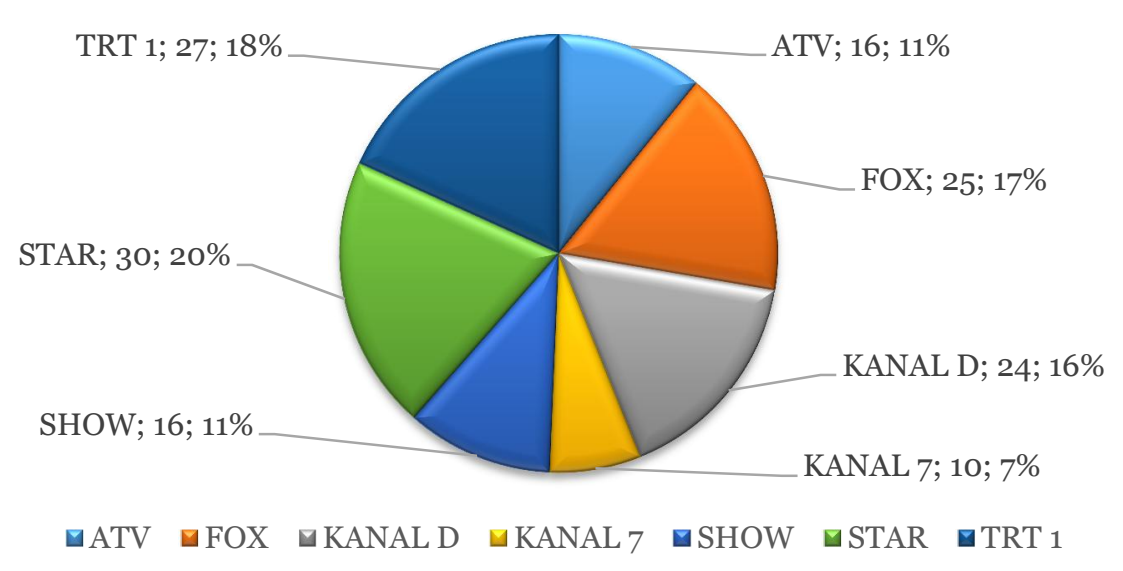

Grafik 2'de dizi adlarında tespit edilen toplam 148 adet sıfat türündeki kelimenin kanallardaki oransal dağılımı verilmiştir. Grafik incelendiğinde dizi adlarında sıfat türündeki kelimelerin en fazla Star'da, en az ise Kanal 7’de kullanıldığı görülmektedir.

\subsubsection{Zamirler}

\subsubsection{1. Şahıs zamirleri}

Dizi adlarında tespit edilen zamirlerin büyük çoğunluğu "ben-sen" gibi karşıt varlıkları ifade eden şahıs zamirleridir. Ancak kitlelere hitap eden bu tür iletişim araçlarında birliktelik ifade eden ve bir olma mesajı içeren çoğul türden şahıs zamirlerine daha fazla yer verilmesi, millet olma bilincini pekiştireceği için önemlidir.

Ben $(1 / 18,1 / 63,1 / 64,1 / 77,2 / 13,2 / 14,2 / 23,2 / 72,2 / 79,3 / 13,3 / 14,4 / 6,4 / 35,5 / 17,5 / 18,6 / 18,6 / 19$, 6/20, 6/21, 6/22, 7/14), biz (1/3, 1/22, 1/63, 1/64, 1/77, 2/20, 3/21), ikimiz (4/22), onlar (7/72), sen $(2 / 37,2,45,2 / 79,2 / 77,7 / 5,3 / 90,6 / 2,6 / 83,7 / 66)$.

\subsection{Belirsizlik zamirleri}

TV dizileri genellikle belirli bir kişinin ya da belirli bir sosyal tabakanın hayatlarından kesitler sunduğu için dizi adlarında belirsizlik zamirlerinden nadiren faydalanılmıştır.

Alayı (7/7), biri (6/38), hepsi (1/41), kimse (1/53).

\subsubsection{3. İşaret zamirleri}

TV dizileri, belirli durumlara ya da belirli şahısların hayatlarına işaret ettiği için bu türden zamirler dizi adlarında pek tercih edilmemiştir.

\begin{tabular}{r|l} 
Adres & Address \\
RumeliDE Dil ve Edebiyat Araştırmalar Dergisi & RumeliDE Journal of Language and Literature Studies \\
Osmanağa Mahallesi, Mürver Çiçeği Sokak, No:14/8 & Osmanağa Mahallesi, Mürver Çiçeği Sokak, No:14/8 \\
Kadıköy - İSTANBUL / TÜRKIYE 34714 & Kadıköy - ISTANBUL / TURKEY 34714 \\
e-posta: editor@rumelide.com & e-mail: editor@rumelide.com, \\
tel: +90 505 7958124, +90 2167730616 & phone: +90 505 7958124, +90 2167730616
\end{tabular}


$\mathrm{Bu}(2 / 21)$, diğerleri (3/42).

\subsection{Soru zamirleri}

Şahıs zamirleri kategorisi dışındaki zamirlerde olduğu gibi dizi adlarında soru zamirleri de sınırlı düzeyde yer almıştır.

Hangimiz (7/36), ne (3/31, 3/74, 5/60), nerdesin (1/34, 2/69).

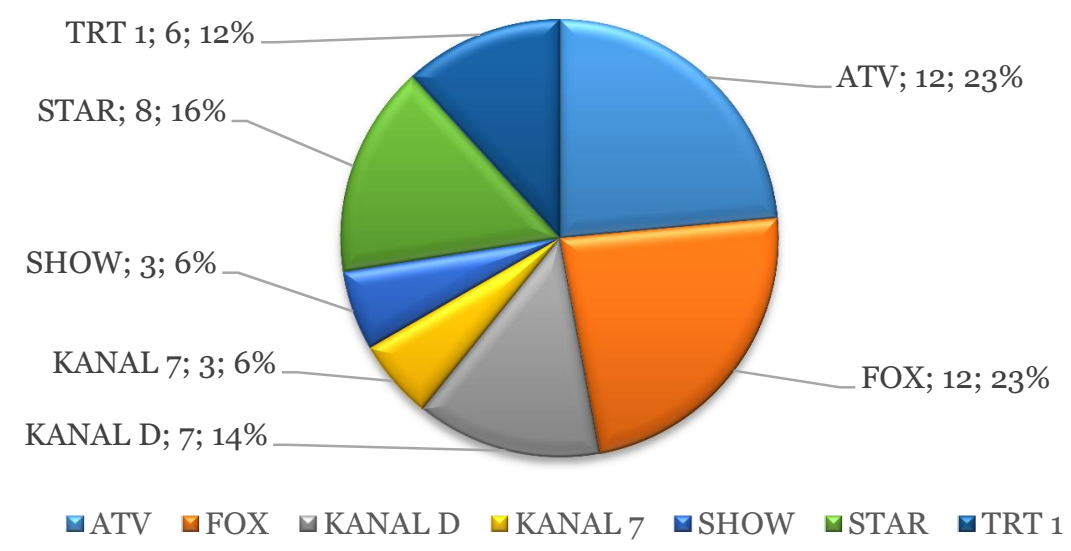

Grafik 3: TV dizi adlarında zamir türündeki kelimelerin kanallara göre oransal dağılımı

Grafik 3 'te dizi adlarında tespit edilen toplam 51 adet zamir türündeki kelimenin kanallardaki oransal dağılımı verilmiştir. Grafik incelendiğinde dizi adlarında zamir türündeki kelimelerin en fazla Fox ile Atv'de, en az ise Show ile Kanal 7'de kullanıldığı görülmektedir.

\subsubsection{Zarflar}

Dizi adlarında anlamlı kelimelerden kullanım sıklı̆̆ı bakımından en az tercih edilen kategori, zarflardır. Aynı zamanda fiiller ve fiil soylu kelimelerden de kullanım sıklığı bakımından en az tercih edilen kategori de zarf-fiillerdir. Dizi adlarında cümle düzeyindeki yapılardan ziyade ad grubu, sıfat grubu gibi yapılara yer verildiği düşünüldüğünde; yüklemi oluşturan çekimli fiilleri durum, zaman, sebep, vasıta gibi çeşitli yönlerden belirleyen zarfların nadiren tercih edilmesi olası bir durumdur.

\subsection{Zaman zarfları}

Dizi adlarında tespit edilen zaman zarfları; geçmiş, bugün ve gelecek için belirli bir zaman dilimine işaret eden kelimeler şeklindedir.

Artık (3/13), bir zamanlar (7/17), bazen (6/49), ezelden (3/88,6/93), hala $(2 / 14,6 / 20)$, önce $(5 / 65)$, şimdi (7/72).

\subsection{Durum zarfları}

Dizi adlarında zarf kategorisinden sıklıkla tercih edileni, durum zarflarıdır.

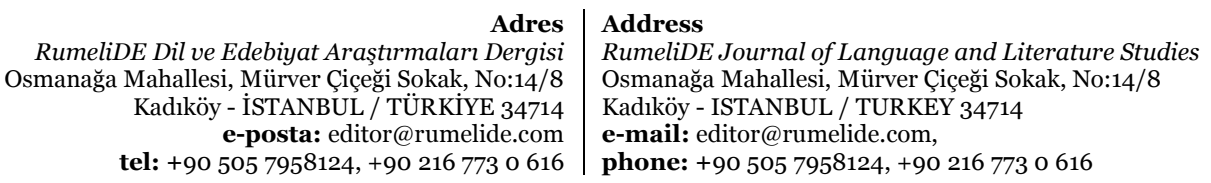


Asla (5/11), baştan (4/38), bir kere (6/83), böyle (7/14, 7/18), en (7/27), inadına (2/47, 3/47), öyle bir (3/76), sensiz $(2 / 80,4 / 34,5 / 69)$, yeniden $(2 / 9,7 / 81)$.

Grafik 4: TV dizi adlarında zarf türündeki kelimelerin kanallara göre oransal dağılımı

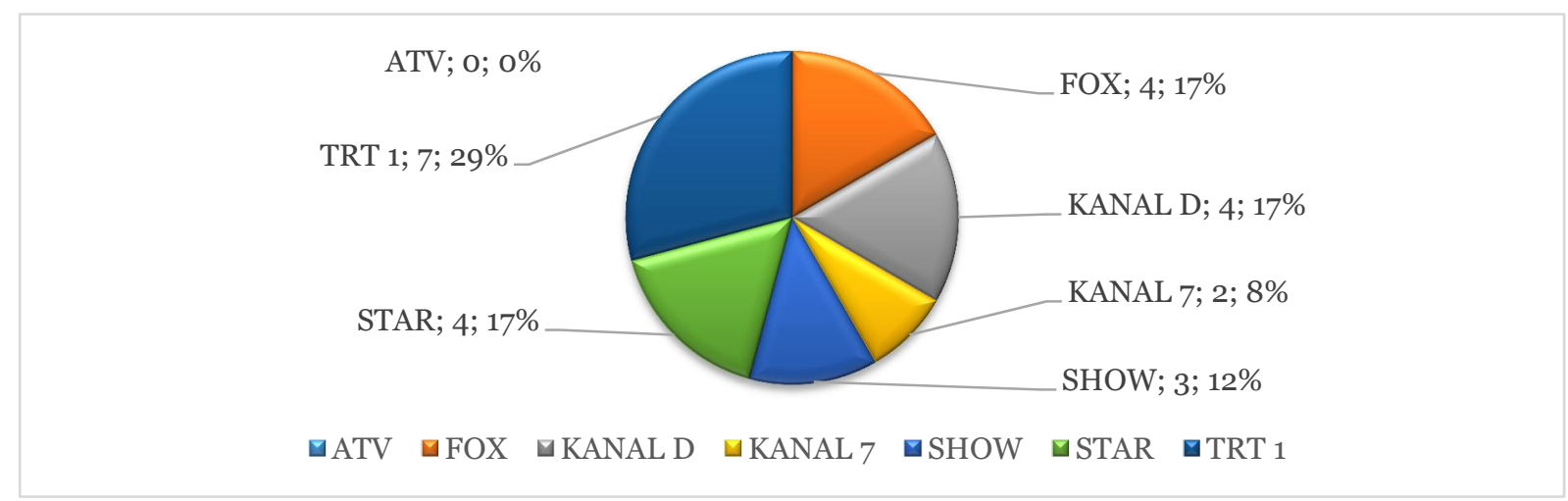

Grafik 4'te dizi adlarında tespit edilen toplam 24 adet zarf türündeki kelimenin kanallardaki oransal dağılımı verilmiştir. Grafik incelendiğinde dizi adlarında zarf türündeki kelimelerin en fazla TRT 1'de, en az ise Kanal 7'de kullanıldığı görülmektedir. ATV'de ise zarf türündeki kelimelerin TV dizi adlarında tercih edilmediği tespit edilmiştir. 
Tablo 1: TV dizi adlarında en sık kullanılan ad ve ad soylu kelimeler

\begin{tabular}{|c|c|c|c|c|c|}
\hline Kelime & Siklık & Kelime & Sikhk & Kelime & Siklik \\
\hline$A s ̧ k$ & 36 & Bedel & 3 & $\dot{I S S}$ & 2 \\
\hline Bir & 23 & Doktor & 3 & Kant & 2 \\
\hline Ben & 21 & Gelin & 3 & Kanun & 2 \\
\hline Hayat & 14 & Kelebek & 3 & Kayıp & 2 \\
\hline Kalp & 11 & Ömür & 3 & Koku & 2 \\
\hline Baba & 10 & Pusu & 3 & Kördüğüm & 2 \\
\hline Aile & 9 & Saat & 3 & Köylü & 2 \\
\hline Çocuk & 9 & Var & 3 & Kraliçe & 2 \\
\hline$K \imath z$ & 9 & Tath & 3 & Lale & 2 \\
\hline Sen & 9 & $\dot{I} k i$ & 3 & Mucize & 2 \\
\hline Hikaye & 8 & $\mathrm{Ne}$ & 3 & Oğlan & 2 \\
\hline İstanbul & 8 & Sensiz & 3 & Rüzgar & 2 \\
\hline Küçük & 8 & Hazreti & 3 & Saadet & 2 \\
\hline Anne & 7 & Büyük & 3 & Servet & 2 \\
\hline Yol & 7 & Kara & 3 & Sinif & 2 \\
\hline Biz & 7 & $A \breve{g} a c ̧$ & 2 & Sosyete & 2 \\
\hline$A d$ & 6 & Akasya & 2 & $\mathrm{Su}$ & 2 \\
\hline Can & 6 & Analı Oğullu & 2 & Suç & 2 \\
\hline$E v$ & 6 & Bahar & 2 & Sürgün & 2 \\
\hline Güzel & 6 & Bebek & 2 & Şarkı & 2 \\
\hline Yalan & 6 & Bulut & 2 & Şehir & 2 \\
\hline Deli & 6 & Cennet & 2 & Vatan & 2 \\
\hline Umut & 6 & Cinayet & 2 & Yabancı & 2 \\
\hline Kurt & 5 & Çiçek & 2 & Yara & 2 \\
\hline Sevda & 5 & Damat & 2 & Yer Gök & 2 \\
\hline Yer & 5 & Deniz & 2 & Umutsuz & 2 \\
\hline Yürek & 5 & Denizyıldızı & 2 & Zengin & 2 \\
\hline Hanım & 5 & Devir & 2 & Nerdesin & 2 \\
\hline Gönül & 4 & Dost & 2 & Ezelden & 2 \\
\hline Gün & 4 & Durak & 2 & Hala & 2 \\
\hline Kardeş & 4 & Durum & 2 & Böyle & 2 \\
\hline Kuş & 4 & Dünya & 2 & Inat & 2 \\
\hline Masal & 4 & Düşman & 2 & Yeniden & 2 \\
\hline Melek & 4 & Ekmek & 2 & Urfalı & 2 \\
\hline Saray & 4 & Elma & 2 & Komiser & 2 \\
\hline Sevgili & 4 & Evlat & 2 & Osmanlı & 2 \\
\hline Sir & 4 & Firtuna & 2 & $\mathrm{Acl}$ & 2 \\
\hline Vadi & 4 & Gül & 2 & Acil & 2 \\
\hline Yalance & 4 & Günah & 2 & Beyaz & 2 \\
\hline Yüzyıl & 4 & $\mathrm{Hal}$ & 2 & Fakir & 2 \\
\hline Zaman & 4 & Hayal & 2 & Geniş & 2 \\
\hline Muhteşem & 4 & İlişki & 2 & $\dot{I} l k$ & 2 \\
\hline Arkadaş & 3 & Intikam & 2 & Kayıp & 2 \\
\hline Ateş & 3 & İnci & 2 & Son & 2 \\
\hline
\end{tabular}

Yukarıdaki tabloda dizi adlarında birden fazla tekrar eden ad ve ad soylu kelimeler ve sıklıkları sıralanmıştır. Dizi adlarında bir kez kullanılan ad ve ad soylu kelimelere bu listede yer verilmemiştir.

\begin{tabular}{|c|c|}
\hline & \\
\hline aları $D$ & d Literatur \\
\hline $\mathrm{Mal}$ & Mahallesi, Mürver Çiçeği Sokak, No:14/8 \\
\hline Kadıköy & STANBUL / TURKEY 34714 \\
\hline $\begin{array}{r}\text { e-posta: edito } \\
\text { tel: }+905057958124,+\end{array}$ & $\begin{array}{l}\text { editor@rumelide.com, } \\
\text { +90 505 7958124, +90 } 216773 \text { o } 616\end{array}$ \\
\hline
\end{tabular}




\subsubsection{Fiiller ve fiil soylu kelimeler}

Dizi adlarında kullanım sıklı̆̆ı bakımından üçüncü sırada fiillerin yer alması, adlar bölümünde de belirtildiği üzere özellikle muhakeme gücünü harekete geçirme amacı taşımaktadır. Tespit edilen fiillerin büyük çoğunluğunun olumsuz formda olması, bireylerin olumsuz olay ve durumları muhakeme ederken kendilerine kıssadan hisse çıkarma mesajı ile açıklanabilir.

\subsubsection{1. Çekimli fiiller}

Ad koy- (4/2, 5/3, 6/2, 7/5), affet- $(1 / 3,5 / 17,6 / 18)$, ağlat- (5/12), aklı başına gel- (4/4), akşam ol(5/42), anlat- (1/63, 2/13), aran- (7/46), aşık ol- (7/43), ayrıl- (2/68), başla- (7/81), bık- (6/88), birakma- (1/18), bilme- (1/53), bitme- (7/18), dayan- (2/28), de- $(3 / 13,3 / 74,7 / 78)$, dinle- $(2 / 33)$, duyma- $(2 / 27,3 / 27)$, düşün- $(7 / 72)$, eline ver- $(3 / 92)$, ferman dinleme- $(5 / 39)$, geç- $(3 / 76)$, gitme(7/66), görme- (1/8), gülümse- (5/41), hatırla- (1/39, 6/48), hükümdar olma- (1/33), kaçlma- (6/8), kal- $(3 / 25,3 / 53)$, kalbine yaz- (5/5), kelepçe vurulma- (2/84), koru- (2/64), n'ol- $(2 / 68)$, ol- $(2 / 19$, $3 / 16,5 / 62)$, olma- (4/34, 5/69), özle- (6/22), saylma- (2/21), sev- (2/4, 2/8, 3/17, 4/35, 4/37, 6/23, $6 / 83,7 / 14)$, sevme- $(7 / 36)$, sinıfta kal- (2/12), sir ver- (2/77), sil- (4/38), üzülme- $(5 / 18)$, vazgeçme(5/11), yapma- $(7 / 78)$, yaşayama- $(2 / 80)$, yet- $(3 / 20,4 / 37,5 / 41)$, yetme- $(6 / 25)$.

\subsubsection{2. Çekimsiz fiiller}

\subsubsection{1. İsim fiiller}

At- (5/47), ateşe yürü- (6/10), ay tutul- (6/13), çarpış- (5/23), çık- (7/69), gör- (2/41), hesaplaş(7/41), korkma- (7/49), kurul- (1/56), sev- (2/13), yaşa- (3/47), yüzleş- (3/98).

\subsection{Sifat fiiller}

Affedilme- (1/2), ağlat- (5/6), canını sev- (7/22), çal- (2/54), çık- (1/49), de- (2/54), diril- (7/25), düş(5/32), gönülçel- (1/37), kaybet- (7/45), kaderi yazıl- (6/60), kız kaçır- (1/52), oyunboz- (5/64), unutul- $(1 / 75)$, ylldırım düş- $(5 / 32)$.

\subsection{Zarf fiiller}

Bekle- (3/36), git- (3/89), kal- (7/39), sev- (2/44), uyu- (3/8).

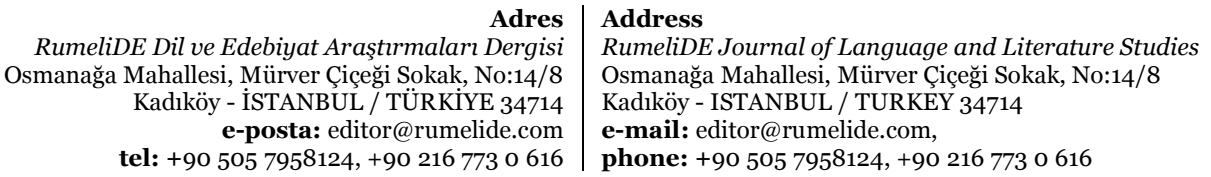

tel: +90 505 7958124, +90 2167730616 
Grafik 5: TV dizi adlarında fiil türündeki kelimelerin kanallara göre oransal dağılımı

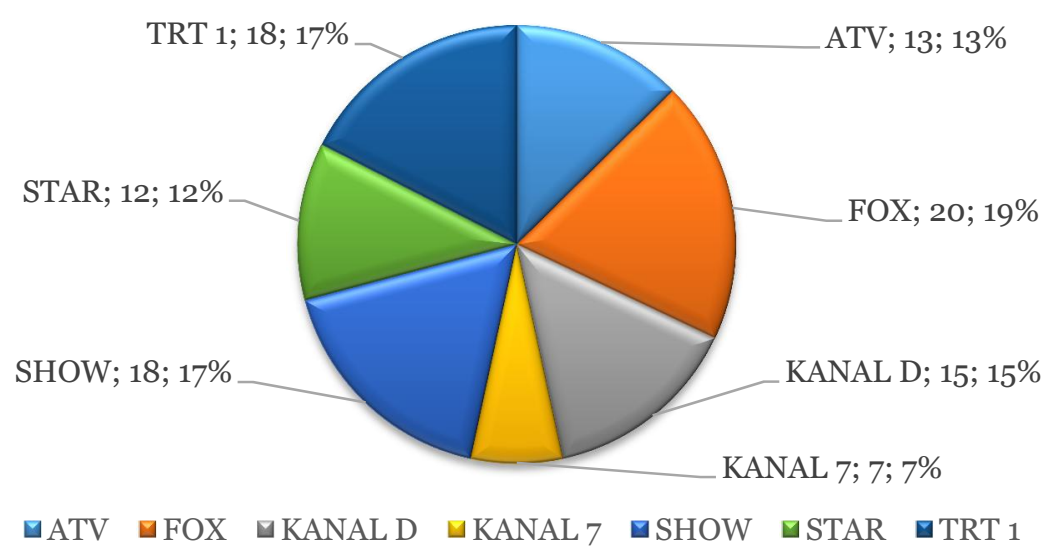

Grafik 5'te dizi adlarında tespit edilen toplam 103 adet fiil türündeki kelimenin kanallardaki oransal dağılımı verilmiştir. Grafik incelendiğinde dizi adlarında fiil türündeki kelimelerin en fazla Fox’ta, en az ise Kanal 7'de kullanıldığı görülmektedir.

Tablo 2: TV dizi adlarında en sık kullanılan fiil ve fiil soylu kelimeler

\begin{tabular}{ll}
\hline Kelime & Siklk \\
\hline Sevmek & 8 \\
Ad koymak & 4 \\
Affetmek & 3 \\
Demek & 3 \\
Olmak & 3 \\
Yetmek & 3 \\
Anlatmak & 2 \\
Duymak & 2 \\
Hatrlamak & 2 \\
Kalmak & 2 \\
Olmamak & 2 \\
& \\
\hline
\end{tabular}

Yukarıdaki tabloda dizi adlarında birden fazla tekrar eden fiil ve fiil soylu kelimeler ile bu kelimelerin sıklıkları listelenmiştir.

\subsection{Görevli kelimeler}

Dizi adlarında tespit edilen görevli kelimelerden kullanım sıklığı en fazla olan tür, bağlaçlardır.

\subsubsection{Bağlaçlar}

Dizi adlarında bağlaç türünden en çok ve, ile bağlaçları tercih edilmiştir.

De (6/22, 7/66), ile (2/18, 2/40, 7/53), ki (3/76), ve (1/11, 1/40, 1/79, 2/55, 3/10, 3/11, 3/12, 3/42, $5 / 14,6 / 6,6 / 16,6 / 29,6 / 39,6 / 68,6 / 74)$. 
Grafik 6: TV dizi adlarında bağlaç türündeki kelimelerin kanallara göre oransal dağılımı

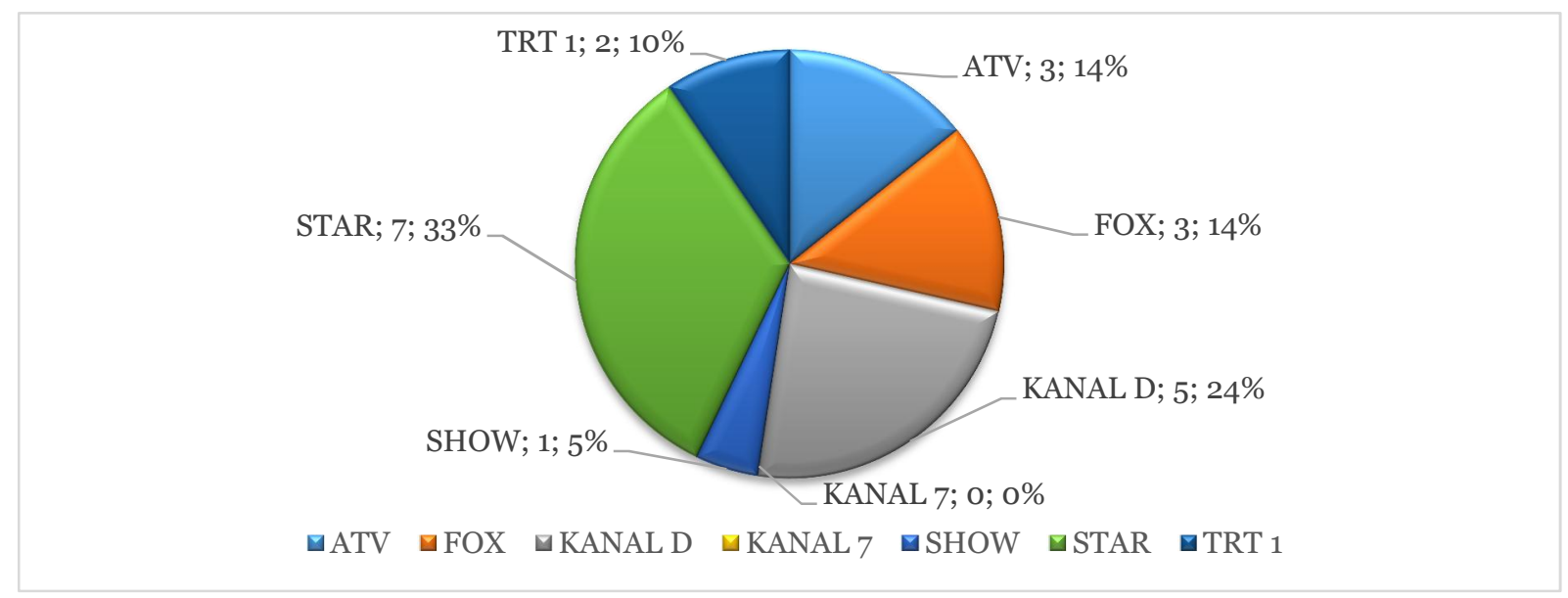

Grafik 6'da dizi adlarında tespit edilen toplam 21 adet bağlaç türündeki kelimenin kanallardaki oransal dağılımı verilmiştir. Grafik incelendiğinde dizi adlarında bağlaç türündeki kelimelerin en fazla Star'da, en az ise Show'da kullanıldığı görülmektedir. Kanal 7’deki dizi adlarında ise bağlaç türündeki kelimelerin tercih edilmediği görülmektedir.

\subsubsection{Edatlar}

Dizi adlarında belirlenen sınırlı sayıdaki edatlardan kullanım sıklığı en fazla olan, için edatıdır.

-den başka (1/64), dek (4/39), gibi (1/32), için (2/11, 3/59, 5/18), sonra (3/96).

Grafik 7: TV dizi adlarında edat türündeki kelimelerin kanallara göre oransal dağılımı

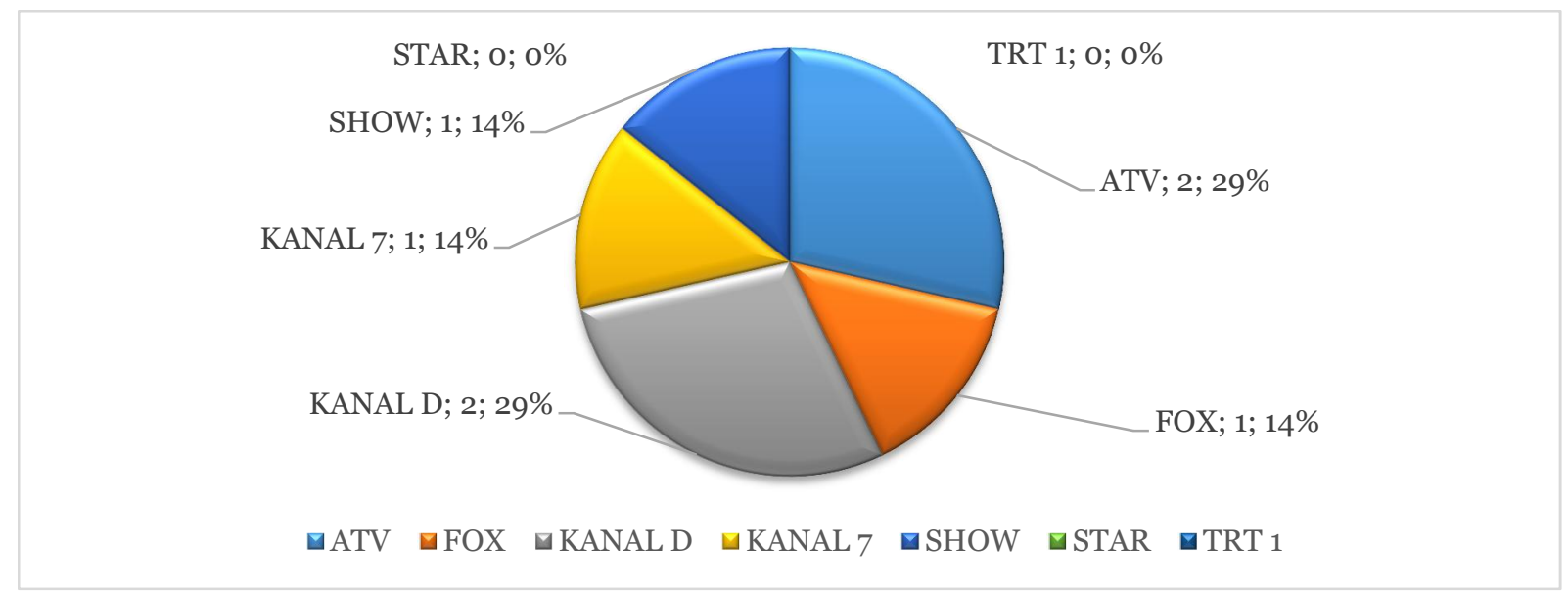

Grafik 7'de dizi adlarında tespit edilen toplam 7 adet edat türündeki kelimenin kanallardaki oransal dağılımı verilmiştir. Grafik incelendiğinde dizi adlarında edat türündeki kelimelerin en fazla Atv ve Kanal D'de, en az ise Fox, Kanal 7 ve Show TV'de kullanıldığı görülmektedir. TRT 1 ve Star'da ise dizi adlarında edat türündeki kelimelerin tercih edilmediği tespit edilmiştir.

\footnotetext{
Adres | Address

RumeliDE Dil ve Edebiyat Araștırmalar Dergisi Osmanağa Mahallesi, Mürver Çiçeği Sokak, No:14/8 Kadıköy - İSTANBUL / TÜRKIYE 34714 e-posta: editor@rumelide.com

RumeliDE Journal of Language and Literature Studies Osmanağa Mahallesi, Mürver Çiçeği Sokak, No:14/8

Kadıköy - ISTANBUL / TURKEY 34714

e-mail: editor@rumelide.com,

tel: +90 $5057958124,+902167730616$ phone: +90 505 7958124, +90 2167730616
} 


\subsection{Anlamlı-görevli kelimeler}

Dizi adlarında ünlemlerden sınırlı sayıda yararlanıldığı görülmektedir. Bu durum, dizi adlarında karşılıklı konuşma veya duyguları harekete geçirme amacından ziyade belirli durum ya da olayları betimleme ve düşünce yetisini ön planda tutma fikri ile izah edilebilir.

\subsection{1. Ünlemler}

Dizi adlarında tespit edilen ünlemlerden kullanım sıklığı en fazla olan $\boldsymbol{a h}$ kelimesidir.

$\operatorname{Ah}(1 / 4,4 / 3,5 / 7,7 / 6)$, aman (1/8), ey (1/34), ulan (3/86).

Grafik 8: TV dizi adlarında ünlem türündeki kelimelerin kanallara göre oransal dağılımı

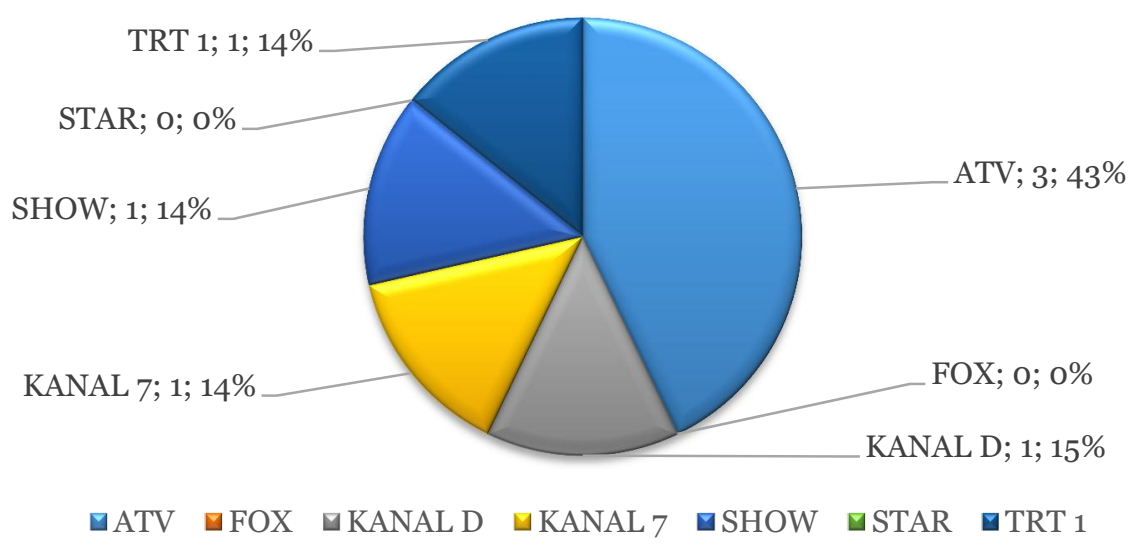

Grafik 8'de dizi adlarında tespit edilen toplam 7 adet ünlem türündeki kelimenin kanallardaki oransal dağılımı verilmiştir. Grafik incelendiğinde dizi adlarında ünlem türündeki kelimelerin en fazla Atv'de, en az ise birer adet olmak üzere Kanal D, Kanal 7, Show, ve TRT 1'de kullanıldığı görülmektedir. Fox ve Star'daki dizi adlarında ünlem türünde kelimelerin tercih edilmediği tespit edilmiştir.

Tablo 3: TV dizi adlarında en sık kullanılan anlamlı ve anlamlı-görevli kelimeler

\begin{tabular}{lc}
\hline Kelime & S1klık \\
\hline Ve & 15 \\
Ah & 4 \\
İle & 3 \\
İçin & 3 \\
De & 2 \\
\hline
\end{tabular}

Yukarıdaki tabloda görevli ve anlamlı-görevli kelimeler kategorisinden dizi adlarında birden fazla tekrar eden kelimeler ve bu kelimelerin sıklıkları listelenmiştir. Bu tabloda dizi adlarında bir kez kullanılan kelimelere yer verilmemiştir. Tablodaki kelimeler kullanım sıklı̆̆ fazla olandan az olana doğru sıralanmıştır.

\footnotetext{
\begin{tabular}{r|l} 
Adres & Address \\
RumeliDE Dil ve Edebiyat Araştırmalar Dergisi & RumeliDE Journal of Language and Literature Studies
\end{tabular} Osmanağa Mahallesi, Mürver Çiçeği Sokak, No:14/8 Osmanağa Mahallesi, Mürver Çiçeği Sokak, No:14/8

Kadıköy - İSTANBUL / TÜRKIYE 34714 Kadıköy - ISTANBUL / TURKEY 34714 e-posta: editor@rumelide.com e-mail: editor@rumelide.com,

tel: +90 505 7958124, +90 2167730616 phone: +90 505 7958124, +90 2167730616
} 


\section{Sonuç}

Türkiye'de en çok izlenen televizyon kanallarında yayınlanan dizi adlarının söz varlığının incelendiği bu çalışmada; Atv'den 80 dizi adında 147 kelime, Fox'tan 90 dizi adında 191 kelime, Kanal D'den 99 dizi adında 193 kelime, Kanal 7'den 44 dizi adında 79 kelime, Show TV'den 79 dizi adında 140 kelime, Star TV'den 97 dizi adında 196 kelime ve TRT 1'den 87 dizi adında 181 kelime olmak üzere toplamda 1131 adet kelime "Anlamlı Kelimeler, Görevli Kelimeler ve Anlamlı-Görevli Kelimeler” başlıkları altında değerlendirilmiştir. Buna göre 1096 adet anlamlı kelimeler kategorisinde 770 kelime ad, 148 kelime sıfat, 51 kelime zamir, 24 kelime zarf, 103 kelime ise fiil türündeyken 28 adet görevli kelimelerden 21'i bağlaç, 7'si edat; 7 adet anlamlı-görevli kelimelerin tamamı da ünlem türündedir:

Dizi adlarında en çok kullanılan tür olan adlar kategorisinden çoğunlukla insanın tasavvur ettiği, varlı̆̆ını kabul ettiği soyut özellikli kavramlar tercih edilmiştir. Sıfat kategorisinden ise daha çok canlı ya da cansız varlıkları renk, tat, koku, şekil, biçim gibi özellikler bakımından tanımlayan nitelik sıfatları kullanılırken zamirlerden en çok şahıs zamirleri, zarflardan durum zarfları, fiillerden ise çekimli fiil türleri kullanılmıştır. Görevli kelimelerden de çoğunlukla bağlaçlara yer verilmiştir.

Dizi adlarında kullanım sıklığı en fazla olan kelime, aşktır. Gerek günlük yaşantıda gerekse Türkçe Sözlük'te açılanırken birbiri yerine kullanılan ve Sevda Masal, Bir Deli Sevda, Kara Sevda, Sevda Kuşun Kanadında dizi adlarından tespit edilen sevda kelimesi ile Aşk ve Mavi, Aşka Sürgün, Aşkın Halleri, İnadına Aşk, İlk Aşk, Aşktan Kaçılmaz dizi adlarında geçen aşk kelimesi her ne kadar eş anlamlı gibi görünse de derin yapıda anlam bakımından farklılıklar barındırmaktadır. İnsan kimyasına uygun bir duygu durumu ya da duygu durumu değişikliğini ifade etmek için daha çok aşk kelimesi kullanılırken; çok daha derin, melankolik bir bağımlılığı ve hissiyatı ifade etmek için de -ait olduğu dil olan Arapçada kara manasına gelen- sevda kelimesi tercih edilmiştir. Yine bu kelimelerde olduğu gibi kalp ve yürek kelimeleri de sıkça tekrar edilen kelimelerdir ki esas itibariyle eş anlamlı olan bu iki kelimenin sıklıkla tercih edilmesi dikkat çekici niteliktedir. Ancak Deli Yürek, Cesur Yürek, Dayan Yüreğim, Tek Yürek dizi adlarındaki yürek kelimesi ile Rüzgarın Kalbi, Kalbim Yangın Yeri, Kalbimin Sultan, Ah Kalbim, Mazi Kalbimde Yaradır dizi adlarındaki kalp kelimesinin mana bakımından kullanım şekillerinde farklılıklar olduğu görülmektedir. İnsana özgü cesur olmak, dayanmak gibi nitelikler organa izafe edildiğinde yani insanda gücü temsil eden meziyetlerle organ arasında bă̆ kurmak için genellikle yürek kelimesi tercih edilirken insanın hissî durumlarını ifade etmek için de daha çok $\boldsymbol{k a l p}$ kelimesi tercih edilmiştir. Dolayısıyla dil denilen olgunun sanıldığı kadar statik olmadığl; aksine her türlü duyguyu, durumu en iyi ifade edecek kelimelerle geliştiği, zenginleştiği verilen örneklerde açıkça görülmektedir. Şunu da belirtmek gerekir ki dilin dokusuna, kaidelerine uydurulan alıntı kelimeler dilden atılmak istenildiğinde, dilin derin mana sistemini bozan farkına varılmadan- yapay bir müdahaleye sebep olunabilir.

Aşk kelimesinden sonra dizi adlarında en çok tekrarlanan bir ve ben, kelime hazinesi araştırmalarının neredeyse tamamında (Göz, 2003, Kılınç, 2020; Ölker, 2011) en sik kullanılan ilk beş kelime içinde yer almaktadır.

Aşk, bir, ben kelimelerinden sonra sıklıkla tekrarlanan kelimeler, Türk kültürünü diğer dünya kültürlerinden ayıran en önemli özelliklerden biri olan aile-akrabalık-dostluk vb. adlarına karşllık gelen baba, aile, kzz, anne, evlat, kardeş, oğlan, gelin, damat, arkadaş kelimeleridir. Türk kültür tarihinde, destanlarda ya da masallarda önemli bir kült olan kurt ve elma dizi adlarında tekrar edilen kelimelerdendir. Ayrıca Müslümanlık inancı çerçevesinde kullanılan melek, hazreti, cennet,

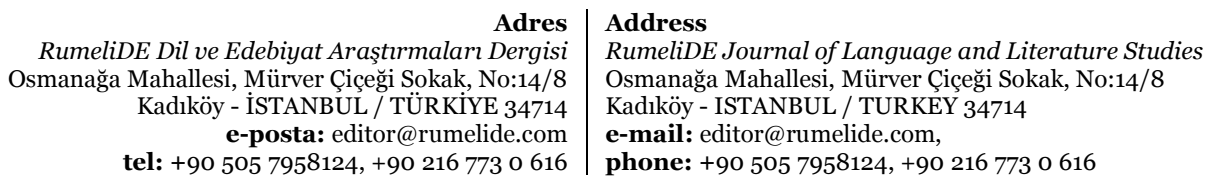


günah gibi kelimeler de dizi adlarında tekrar edilen kelimelerdendir. Bununla birlikte dizi adlarında sık tercih edilen deli, yalan, yalancı, bedel, sır, pusu, düşman, intikam, ilişki, kördü̈̆üm, kant, kanun gibi kelimeler dizilerde işlenen sosyal yaşantılardaki özellikle olumsuz durum, davranış ya da tutumların neticelerine dikkat çekerek mesaj verme amaçlı kullanılmıştır. Yine dizi adlarında en çok tekrar edilen yer adı olan İstanbul'da sosyal statü farklılıklarına bağlı gelişen çarpık ilişkileri konu edinen dizilerin adlarında köylü, kraliçe, servet, sosyete, zengin, fakir, durum gibi kelimeler slk sık tercih edilmiştir.

Dizi adlarında en çok tekrarlanan ortak ad, aşk olduğu gibi fiillerden de sevmek en slk kullanılan kelimedir. Sevmek dışında yukarıda zikredilen çalışmalarda da olduğu gibi demek, olmak, olmamak kelimeleri sıkça kullanılmıştır. Yine aynı kaynaklarda olduğu üzere dizi adlarında da en sık kullanılan görevli kelime "ve"dir.

Dil öğretiminden kültürler arası etkileşime kadar pek çok konuda tüm dünyada en yaygın araçlardan birinin televizyon olduğu gerçeğine bağlı olarak bu platformda kullanılan dilin kendi kurallarına, sesşekil özelliklerine uygun olması etkili ve doğru iletişimin ön koşulu ve aynı zamanda ait olduğu milletin ve devletin de bekası açısından son derece önemli bir mevzudur.

Yapılan çalışma ile günümüzde en yaygın iletişim araçlarından biri olan televizyon özelindeki diziler adlandırılırken kullanılan kelimelerin tür kategorileri ve bu kelimelerin kanallardaki sıklıkları tespit edilmiştir. Aynı zamanda madde başı kelime çeşitliliği ve bu kelimelerin sıklıkları da irdelenmiştir. Kelime sıklı çalışmaları, tüm dünyada olduğu gibi ülkemizde de özellikle son yıllarda giderek önem kazanan araştırma sahalarından biridir. Gerek ana dil gerekse yabancı dil öğretiminde, gündelik hayatta sık kullanılan kelimelerin öncelikli öğretimiyle zamandan tasarruf edip etkin bir öğrenme süreci oluşması noktasında her dil için kelime sıklığı sözlüklerinin oluşturulması elzemdir. Dizi adlarında standart Türkçenin ses-şekil ve anlam özelliklerine uygun bir şekilde hareket edildiği görülmüştür. Yalnız bazı dizi adlarında sınırlı sayıda birkaç kelimenin yazımı ile ilgili yanlışlıklar yapılmıştır (Ekler-1: Tablo 6).

Hem Türkçedeki kelime türlerinin sıklığını hem de en çok tekrar eden kelimelerin tespiti ile ulaşılan kelime sıklıklarını, kitle iletişim araçlarından televizyonda yayınlanan dizi adları bağlamında irdeleyen bu çalışmanın konuyla ilgili yapılabilecek başka çalışmalara fikir sunması umulmaktadır.

\section{Kaynakça}

Akınerdem, F. (2012). Yerli dizi anlatıları ve izleyici katılımı: Uçurum dizisini Ekşisözlük ve Twitter'la birlikte izlemek. Folklor/Edebiyat, 18(72), 77-89.

Akman, T. (2013). Ortaöğretim dil ve edebiyat kitaplarında kelime sıkhı̆ı çalışması. Yayımlanmamış Yüksek Lisans Tezi, Konya: Necmettin Erbakan Üniversitesi Eğitim Bilimleri Enstitüsü

Aksan, D. (2003). Her yönüyle dil ana çizgileriyle dilbilim. Ankara: TDK.

Aksan, D. (2006). Türkçenin sözvarhı̆̆ı. Ankara: Engin.

Aksan, D. (2006). Anadilimizin söz denizinde. Ankara: Bilgi.

Aksan, Y. ve Aksan, M. (2016). Türkçenin derlem temelli sıklık sözlüğü: temel ilkeler ve uygulama. Sakarya: Uluslararası Sözlük Bilimi Sempozyumu, 81-93.

Akyalçın, N. ve Aydoğan, D. (2019). Dede Korkut Hikâyeleri'nde yer alan kalıp sözler üzerine bir değerlendirme. Homeros, 2(4), 155-164.

\footnotetext{
RumeliDE Dil ve Edebiyat Araşttrmaları Dergisi Osmanağa Mahallesi, Mürver Ciçeği Sokak, No:14/8 Kadıköy - İSTANBUL / TÜRKIYE 34714 e-posta: editor@rumelide.com tel: +90 $5057958124,+902167730616$ 
Armut, M. (2018). Yozgat'tan derlenen Türk mânilerinin söz varlığı üzerine bir araştırma. Sosyal, Beşeri ve İdari Bilimler Dergisi, 1(2), 43-54.

Ayan, S. ve Baş B. (2015). Çizgi Filmlerdeki söz varlığıyla ilkokul öğrencilerinin söz varlığı üzerine bir araştırma. Ana Dili Ĕğitimi Dergisi, 3(4), 84-99.

Aytaç, A. (2018). Aşkî̀nin Heft Peyker mesnevisinde bulunan deyimler üzerine. Divan Edebiyatı Araştırmaları Dergisi, 20: 101-118.

Baş, B. (2011). Söz varlığı ile ilgili çalışmalarda kullanılacak ölçütler. TÜBAR, XXIX, 27-61.

Bayram, M.F. (2018). Türkiye'de "sahte ihtiyacın" kaynağ olarak dizi filmler. Yayımlanmamış Yüksek Lisans Tezi, Ankara: Hacettepe Üniversitesi Sos. Bil. Enstitüsü.

Bulak, Ş. (2016). Bir mikro üslup inceleme denemesi: Ahmed Arifin Merhaba, İçerde, Ay Karanlık, şiirlerinde üslup. A. Ü. Türkiyat Araştırmaları Ens. Dergisi, 55, 277-304.

Bulut, S. (2012). Anadolu ağızlarında kullanılan kalıp sözler ve bu kalıp sözlerin kullanım özellikleri. Turkish Studies, 7(4), 1117-1155.

Buran, A. ve Yüksel Çak, B. (2012). Türkiye'de diller ve etnik gruplar. Ankara: Akçağ.

Çal, A. (2015). Türkiye'de farklı dönemlere ait kelime sıklı̆̆ı çalışmaları üzerine bir değerlendirme. Turkish Studies, 10(89), 715-730.

Coşkun, M. (2012). Üslup çalş̧maları üzerine. Nesrin İnşası: Düz yazıda dil, üslup ve türler (Eski Türk Edebiyatı Çalışmaları V). İstanbul: Turkuaz.

Çitgez, M. (2018). Dede Korkut Hikâyeleri’nin söz varlı̆ı. Yayımlanmamış Doktora Tezi, Ardahan: Ardahan Üniversitesi Sosyal Bilimler Enstitüsü.

Çotuksöken, Y. (1989). Bir dilin sözvarlı̆̆ı. Varlkk, 987, 11.

Daşman, A. (2017). Kadın ve kadın leksikolojisinin anlambilimsel özellikleri. SD ̈̈ Fen-Edebiyat Fakültesi Sosyal Bilimler Dergisi, 41, 113-122.

Demirtaş, A. (2019) "Sanal ortam"daki yazışma dilinin Türkçeye etkisi üzerine. International Human and Civilization Congress from Past to Future Kongresi Kongre Kitabl, (387-394), Alanya.

Ergin, M. (2012). Türk dil bilgisi. İstanbul: Bayrak Basım.

Erol, Ç. (2007). Türkiye Türkçesinde kalıp sözler üzerine bir inceleme. Yayımlanmamış Yüksek Lisans Tezi, İstanbul: İstanbul Üniversitesi, Sosyal Bilimler Enstitüsü.

Göz, İ. (2003). Yazıl Türkçenin kelime sıklı̆̆ sözlüğü. Ankara: TDK.

Güllüdă̆, N. (2012). Yazılı ve görsel basında dil estetiği. 21. Yüzyılda Eğitim ve Toplum, 1(1), 49-58.

Güzel, E. ve Karakurt, A. (2001). Dil yozlaşması ve söyleyiş bozukluğu: televizyon reklamlarının göstergebilimsel açıdan çözümlenmesi. Balkan ve Yakın Doğu Sosyal Bilimler Dergisi, 2(4), 115 .

Güzel, A. ve Karadağ, Ö. (2013). Kelime sıklı̆̆ı açısından Türk atasözleri üzerine bir değerlendirme. Mersin Üniversitesi Ĕ̆itim Fakültesi Dergisi, 9(1), 274-280.

Harmanda, S. vd. (2011). Gazi üniversitesi edebiyat fakültesi çağdaş Türk lehçeleri ve edebiyatları bölümü öğrencileri üzerinde kelime hazinesi araştırması. Gazi Türkiyat, 9, 221-244.

Hepçilingirler, F. (2005). Türkçe “OFF”. İstanbul: Remzi.

Hirik, E. (2017). Türkiye Türkçesi duyu fiillerinde anlam ve kelime sıklı̆̆ ilişkisi . SUTAD, 41, 53-74

Kahraman, M. (2017). Türk dilinin Cumhuriyet devri terimsel gelişim sürecine tarihi bakış (II), İnsan ve Toplum Bilimleri Araştırmaları Dergisi, 6(2), 1289-1312.

Kaplan, M. (2010). Kültür ve dil. İstanbul: Dergâh.

Karababa, S. (2013). Feyza Hepçilingirler’in romanlarında söz varlığı. Yayımlanmamış Yüksek Lisans Tezi, Denizli: Pamukkale Üniversitesi Eğitim Bilimleri Enstitüsü.

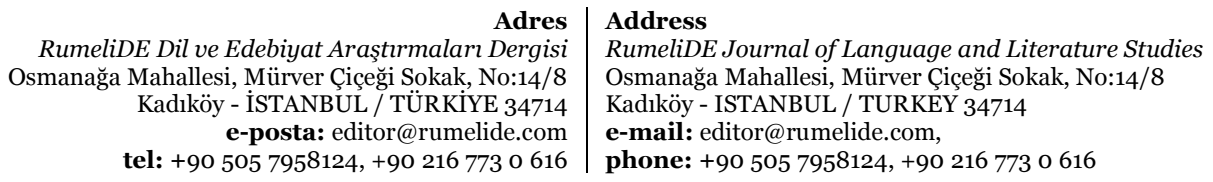


Karadeniz, B. B. (2018). Yaşar Kemal’in "Ağrıdağı Efsanesi” adl romanının söz varlı̆̆ bakımından incelenmesi. Yayımlanmamış Yüksek Lisans Tezi, İstanbul: İstanbul Kültür Üniversitesi Sosyal Bilimler Enstitüsü.

Karagöl, E. ve Tarakcı, R. (2019). Söz varlığı öğretimi açısından ortaokul Türkçe ders kitapları, Milli Ĕ̆itim, 48(222), 149-171.

Karahan, L. (1999). Radyo ve televizyon yayınlarında yöresel söyleyiş sorunu, radyo ve televizyon yayınlarında Türk dilinin kullanımı - Tebliğler (25-26 Kasım 1998-Ankara), Ankara, 53-57.

Kılınç, O. (2020). Sevinç Çokum'un "Bizim Diyar” romanında söz varlığı. Uluslararası Sosyal Araştirmalar Dergisi, 13(71), 58-65.

Korkmaz, Z. (2009). Türkiye Türkçesi grameri şekil bilgisi. Ankara: TDK.

Kurt, B. (2019). Kelime eğitiminin temel kavramları. Ü. Şen (Ed.), Dil eğitiminin temel kavramları. Ankara: Pegem Akademi.

Kurtdaş, M. Ç. (2018). Jean Baudrilliard'ın simülasyon kuramında kitle iletişim araçları ve toplumsalın sonu. Hitit Üniversitesi Sosyal Bilimler Enstitüsü Dergisi, 11(3), 2012-2023.

Lüle Mert, E. (2012). Türkçenin sözvarlığı açısından Eflatun Cem Güney’in derleyip yazdığı masallar. Edebiyat Fakültesi Dergisi, 27(2), 79-97.

Ölker, G. (2011). Yazılı Türkçenin Kelime Sıklığı Sözlüğ̈̈ (1945-195o Arası). Konya: Kömen.

Sever, S. ve Karagül, S. (2014). Oğuz Tansel'in derleyip yazdığı masal kitaplarında yer alan sözvarlı̆̆ı ögelerinin incelenmesi. Cyprus Folklor Edebiyat, 20(77), 17-187.

Soydan, S. (2018). Tarama Sözlüğü’nün İlk üç cildinde kadın ve mutfak eşyaları hakkında kısmî söz varlığı çalışması. Uluslararası Türkçe Edebiyat Kültür Eğitim Dergisi, 7(2), 705-733.

Tosunoğlu, M. ve Melanlığlu, A. (2005). Süheyl ü Nev-Bahâr'ın Türkçe söz varlı̆̆ı ve Anadolu ağızları. Belleten, 1, 189-199.

Türkben, T. (2018). Ömer Seyfettin hikâyelerinin Türkçenin söz varlığı bağlamında incelenmesi. TÜBAR, XLIV, 215-251.

Türkçe Sözlük. (2005). Ankara: TDK.

Türker, A. ve Kırık A. M. (2019). Tarih dizisinde gerçeklik algısının oluşumu: Diriliş Ertuğrul dizisinin göstergebilimsel çözümlemesi. TRTakademi, 4(8), 489-512.

Uçar, İ. ve Adaklı, A. (2019). Seydî Ali Reis'in Hulâsatü’l-Hey'et adlı eserindeki astronomi terimleri, Diyalektolog, 21, 1-22.

Uçar, M. (2013). Anadolu ağızlarında kadının söz varlığına dair bir tasnif denemesi, Turkish Studies, $8(9), 2465-2485$.

Ulutaş, M. ve Kara, M. (2020). Türk atasözlerinde sık kullanılan kelimeler üzerine bir değerlendirme. RumeliDE, 21, 223-241.

Wellington, J. (2006). Educational Research: Contemporary Issues and Pratical Approaches. London: Continuum.

Yalçın, M. (2016). Popüler kültür ürünü olarak Türk televizyon dizilerinde etnografik iletişim kodların kullanımı: Diriliş Ertuğrul dizisi örneği. İnsan ve Toplum Bilimleri Araştırmaları Dergisi, 5(7), 2332-2341.

Yenen Avcı, Y. (2014). Cahit Uçuk'un “Türk İkizleri” romanında sözvarlığı. Cyprus Folklor Edebiyat, 20(78), 121-129.

Yılmaz, A. (2020). Radyo ve sosyal medya yakınsaması: TRT Radyo ve TRT FM'in Facebook ve Twitter pratikleri. TRTakademi, 5(9), 28-50.

Yılmaz, Y. ve Özkurt, E. (2016). Türkiye'de tv program adlarında Türkçeye uygunluk. Rumelide Dil ve Edebiyat Araştırmaları Dergisi, 7 (1), 1-19.

\begin{tabular}{r|l} 
Adres & Address \\
RumeliDE Dil ve Edebiyat Araşttrmaları Dergisi & RumeliDE Journal of Language and Literature Studies \\
Osmanağa Mahallesi, Mürver Çiçeği Sokak, No:14/8 & Osmanağa Mahallesi, Mürver Çiçeği Sokak, No:14/8 \\
Kadıköy - ISTANBUL / TÜRKIYE 34714 & Kadıköy - ISTANBUL / TURKEY 34714 \\
e-posta: editor@rumelide.com & e-mail: editor@rumelide.com, \\
phone: +90 505 7958124, +90 2167730616
\end{tabular}




\section{İnternet erişimleri}

https://dizi.yazarokur.com/trt-1-dizileri (Erişim Tarihi:16.03.2020).

https://sozluk.gov.tr (Erişim Tarihi:12.03.2020).

https://tiak.com.tr/tablolar\#aylik-tablolar_(Erişim Tarihi:01.03.2020).

https://www.atv.com.tr/diziler/arşiv (Erişim Tarihi:18.03.2020).

https://www.diziler.com/kanal/Fox-tv/dizileri (Erişim Tarihi:05.03.2020).

https://www.diziler.com/showtv/dizileri (Erişim Tarihi:03.03.2020).

https://www.Fox.com.tr/dizi-izle (Erişim Tarihi:03.03.2020).

https://www.kanal7.com.tr/dizi-izle (Erişim Tarihi:07.03.2020).

https://www.kanald.com.tr/diziler/arşiv (Erişim Tarihi:06.03.2020).

https://www.startv.com.tr/site-haritası (Erişim Tarihi:11.03.2020).

\section{Ekler 1}

Aşağıdaki tabloda görüldüğü üzere 7 televizyon kanalından derlenen 576 dizi adında, 1096 adet anlamlı kelime, 28 adet görevli kelime ve 7 adet anlamlı-görevli kelime olmak üzere 1131 adet kelime kullanılmıştır.

Tablo 4: TV dizi adlarında kelime türlerinin sayısal dağılımı

\begin{tabular}{|c|c|c|c|c|c|c|c|}
\hline Kelime türleri & ATV & FOX & KANAL D & KANAL $_{7}$ & SHOW & STAR & TRT 1 \\
\hline \multicolumn{8}{|l|}{ Adlar } \\
\hline Ortak adlar & 73 & 110 & 100 & 43 & 75 & 121 & 88 \\
\hline Kişi adları & 12 & 12 & 22 & 8 & 10 & 7 & 11 \\
\hline Lakaplar & 5 & - & 1 & - & 3 & 2 & 1 \\
\hline Unvanlar & 1 & 1 & 2 & 3 & 1 & 3 & 5 \\
\hline Millet vb. adlar & - & - & - & - & 1 & - & 2 \\
\hline Kit'a, ülke vb. adlar & 6 & 1 & 7 & 1 & 3 & 1 & 9 \\
\hline Kurum, okul, otel, vb. adlar & - & 1 & - & - & 1 & - & - \\
\hline Astronomi ile ilgili adlar & - & - & - & - & 1 & - & - \\
\hline Gazete, dergi, roman vb. adlar & 1 & 1 & 3 & - & 2 & 1 & 1 \\
\hline Şarkı, türkü vb. adlar & - & - & - & - & - & - & 3 \\
\hline \multicolumn{8}{|l|}{ Sifatlar } \\
\hline Niteleme sıfatları & 12 & 17 & 16 & 7 & 15 & 24 & 23 \\
\hline İşaret sıfatları & - & 1 & - & - & - & - & - \\
\hline Sayı sıfatları & 4 & 1 & 6 & 3 & - & 4 & 4 \\
\hline Belgisiz sifat & - & 6 & 2 & - & 1 & 2 & - \\
\hline \multicolumn{8}{|l|}{ Zamirler } \\
\hline Şahıs zamirleri & 9 & 10 & 4 & 3 & 2 & 7 & 4 \\
\hline Belirsizlik zamirleri & 2 & - & - & - & - & 1 & 1 \\
\hline İşaret zamirleri & - & 1 & 1 & - & - & - & - \\
\hline Soru zamirleri & 1 & 1 & 2 & - & 1 & - & 1 \\
\hline \multicolumn{8}{|l|}{ Zarflar } \\
\hline Zaman zarfları & - & 1 & 2 & - & 1 & 3 & 2 \\
\hline Durum zarfları & - & 3 & 2 & 2 & 2 & 1 & 4 \\
\hline \multicolumn{3}{|c|}{$\begin{array}{r}\text { Adres } \\
\text { RumeliDE Dil ve Edebiyat Arasstrmaları Dergisi } \\
\text { Osmanağa Mahallesi, Mürver Ciçĕgi Sokak, No:14/8 } \\
\text { Kadıköy - İSTANBUL / TÜRKIYE } 34714 \\
\text { e-posta: editor@rumelide.com } \\
\text { tel: }+905057958124,+90216773 \text { o } 616\end{array}$} & \multicolumn{5}{|c|}{$\begin{array}{l}\text { Address } \\
\text { RumeliDE Journal of Language and Literature Studies } \\
\text { Osmanağa Mahallesi, Mürver Cicceği Sokak, No:14/8 } \\
\text { Kadıköy - ISTANBUL / TURKEY } 34714 \\
\text { e-mail: editor@rumelide.com, } \\
\text { phone: +90 505 7958124, +90 } 216773 \text { o } 616\end{array}$} \\
\hline
\end{tabular}




\begin{tabular}{llllllll}
\hline Fiiller & 7 & & & & & \\
Çekimli fiiller & 7 & 15 & 10 & 7 & 12 & 9 & 11 \\
İsim fiiller & 1 & 2 & 2 & - & 2 & 2 & 3 \\
Sifat fiiller & 5 & 2 & - & - & 4 & 1 & 3 \\
Zarf fiiller & - & 1 & 3 & - & - & - & 1 \\
\hline Bağlaçlar & 3 & 3 & 5 & - & 1 & 7 & 2 \\
\hline Edatlar & 2 & 1 & 2 & 1 & 1 & - & - \\
\hline Ünlemler & 3 & - & 1 & 1 & 1 & - & 1 \\
\hline
\end{tabular}

Tablo 4 incelendiğinde, Atv'de 98 adet ad, 16 adet sıfat, 12 adet zamir, 13 adet fiil, 3 adet bağlaç, 2 adet edat ve 3 adet ünlem türündeki kelimelerin kullanıldı̆̆ı görülmektedir. Yine Atv'de zarf türündeki kelimelerin tercih edilmediği de tespit edilmiştir. Fox'ta 126 adet ad, 25 adet sıfat, 12 adet zamir, 4 adet zarf, 20 adet fiil, 3 adet bağlaç, 1 adet edat türündeki kelimelerin kullanıldığı görülmektedir. Yine Fox'ta ünlem türündeki kelimelerin tercih edilmediği tespit edilmiştir. Kanal D'de 135 adet ad, 24 adet sifat, 7 adet zamir, 4 adet zarf, 15 adet fiil, 5 adet bağlaç, 2 adet edat ve 1 adet ünlem türündeki kelimelerin kullanıldığı görülmektedir. Kanal 7'de 55 adet ad, 10 adet sifat, 3 adet zamir, 2 adet zarf, 7 adet fiil, 1 adet edat ve 1 adet ünlem türünde kelime kullanıldığı görülmektedir. Yine Kanal 7 'de bağlaç türündeki kelimelerin tercih edilmediği tespit edilmiştir. Show'da 97 adet ad, 16 adet sifat, 3 adet zamir, 3 adet zarf, 18 adet fiil, 1 adet bağlaç, 1 adet edat ve 1 adet ünlem türündeki kelimelerin kullanıldığı görülmektedir. Star'da 135 adet ad, 30 adet sıfat, 8 adet zamir, 4 adet zarf, 12 adet fiil ve 7 adet bağlaç kullanıldığı görülmektedir. Star'da edat ve ünlem türündeki kelimelerin tercih edilmediği tespit edilmiştir. TRT 1'de 120 adet ad, 27 adet sıfat, 6 adet zamir, 6 adet zarf, 18 adet fiil ve 1 adet ünlem ile 2 adet bağlaç türündeki kelimelerin kullanıldığı görülmektedir. Yine TRT 1 'de edat türündeki kelimelerin tercih edilmediği görülmüsstür.

Grafik 9: Anlamlı kelimelerin tüm tv kanallarındaki oransal dağılımı

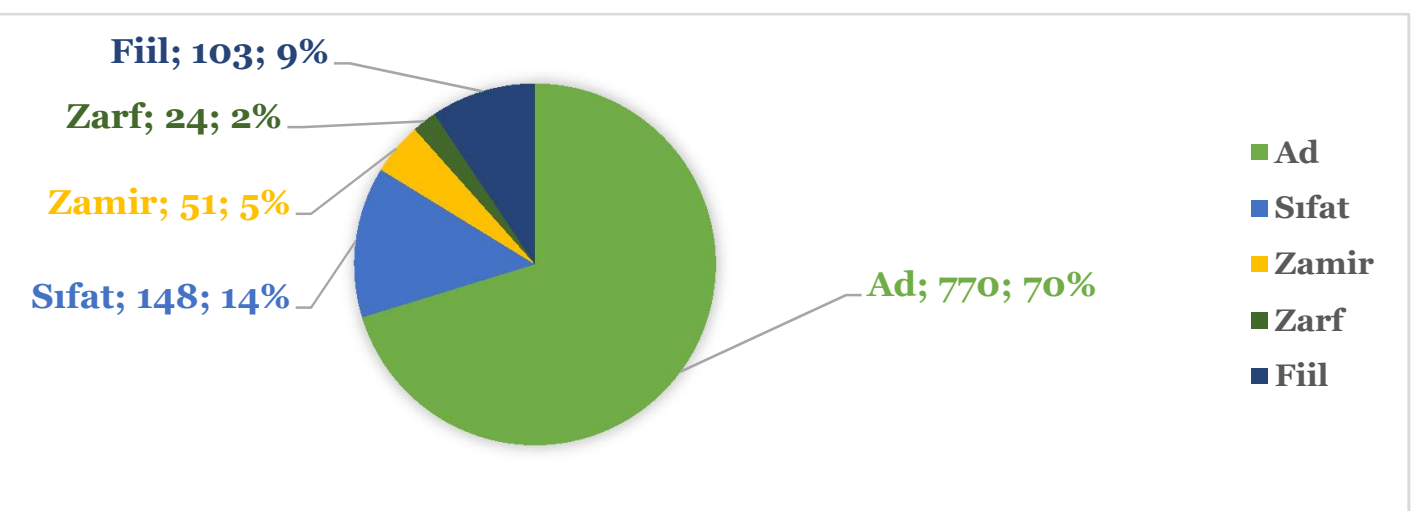

Grafik 9'da anlamlı kelimelerin tüm televizyon kanalındaki oransal dağılımı verilmiştir. Buna göre 1096 adet anlamlı kelimeler kategorisini 770 adet ad, 148 adet sıfat, 103 adet fiil, 51 adet zamir ve 24 adet zarf türündeki kelimeler oluşturmaktadır.

Grafik 10: Görevli kelimeler ve anlamlı-görevli kelimelerin tüm tv kanalındaki oransal dağılımı

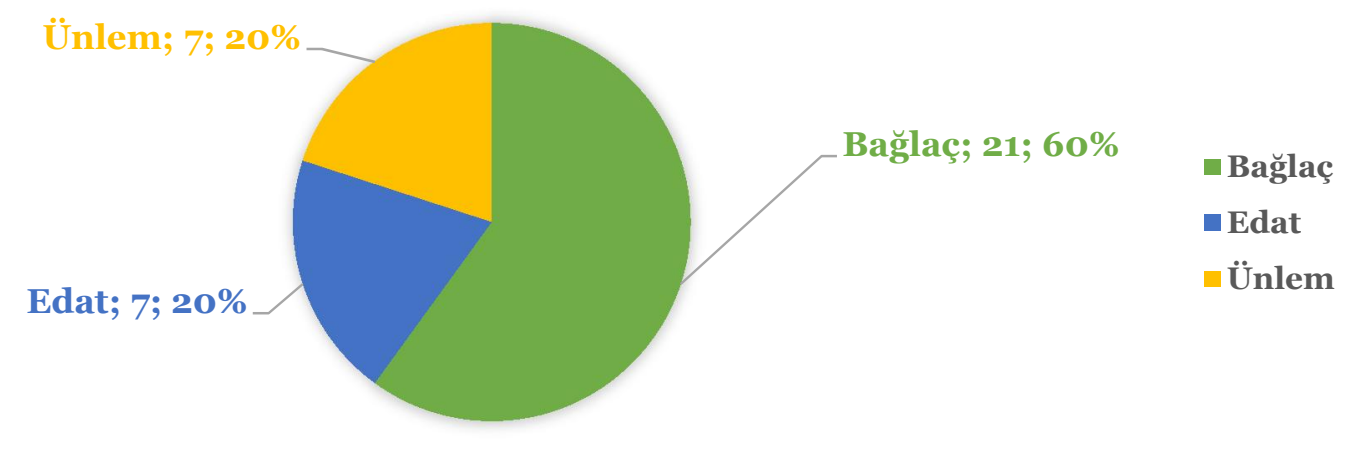


Grafik 10'da televizyon dizi adlarında kullanılan 28 adet görevli kelime ve 7 adet anlamlı-görevli kelimenin oransal dağılımı verilmiştir. Televizyon dizi adlarında görevli kelimeler ve anlamlı-görevli kelimelerden en fazla bağlaçların kullanıldığı; yedişer adet ise edat ve ünlem türünde kelime kullanıldığı görülmektedir.

Tablo 5: Farklı ve toplam kelime sayıları

\begin{tabular}{lc}
\hline Kelime & Sayısal Değer \\
\hline Farklı Kelime Sayısı & 661 \\
Tekrar Edilen Kelime Sayısı & 470 \\
Toplam Kelime Sayısı & 1131 \\
\hline
\end{tabular}

Yukarıdaki tabloda görüldüğü üzere dizi adlarında 661 kelime madde başı olarak belirlenmiştir. Bu kelimelerin toplam sıklığı 1131'dir.

Tablo 6: Yazımında yanlışlık yapılan kelimeler (https://sozluk.gov.tr, Erişim Tarihi:12.03.2020).

\begin{tabular}{ll}
\hline Yazımı Yanlış Kelimeler & Yazımı Doğru Kelimeler \\
\hline Bir Aşk Hikayesi & Bir Aşk Hikâyesi \\
Dükkan & Dükkân \\
Heradot & Herodot \\
Kayıtdışı & Kayıt Dışı \\
Medcezir & Metcezir \\
Mehmed & Mehmet \\
No & Numara \\
N’olur & Ne Olur \\
Nerdesin & Neredesin \\
Sevdaluk & Sevdalık \\
Urfalıyam & Urfalı’yım \\
\hline
\end{tabular}

Tablo 6'da dizi adlarındaki yazım yanlışları ve bu yanlışların düzeltilmişs şekilleri verilmiştir.

\section{Ekler 2}

Tablo 7: Reyting bazında en çok izlenen televizyon kanallarında yayınlanan diziler

\begin{tabular}{|c|c|c|}
\hline Kanal adı & \multicolumn{2}{|l|}{ Dizi adları } \\
\hline Atv & \multicolumn{2}{|c|}{ 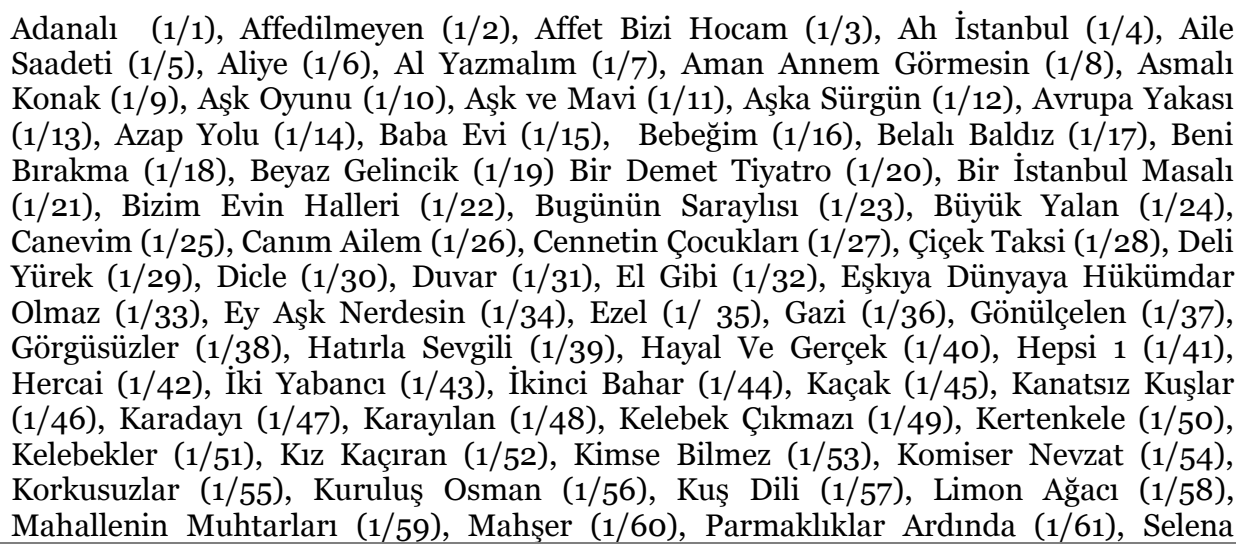 } \\
\hline & $\begin{array}{r}\text { Adres } \\
\text { Dil ve Edebiyat Arasstrrmaları Dergisi } \\
\text { Iahallesi, Mürver Ciçegi Sokak, No:14/8 } \\
\text { Kadıköy - İSTANBUL / TÜRKIYY 34714 } \\
\text { e-posta: editor@rumelide.com } \\
\text { : +90 505 7958124, +90 216 } 7730616\end{array}$ & $\begin{array}{l}\text { Address } \\
\text { RumeliDE Journal of Language and Literature Studies } \\
\text { Osmanağa Mahallesi, Mürver Cicceği Sokak, No:14/8 } \\
\text { Kadlköy - ISTANBUL / TURKEY } 34714 \\
\text { e-mail: editor@rumelide.com, } \\
\text { phone: +90 505 7958124, +90 } 216773 \text { o } 616\end{array}$ \\
\hline
\end{tabular}


(1/62), Sen Anlat Karadeniz (1/63), Senden Başka (1/64), Servet Avcısı (1/65), Sessiz Gemiler (1/66), Sicak Saatler (1/67), Sila (1/68), Sinekli Bakkal (1/69), Süper Baba (1/70), Şahin Tepesi (1/71), Şöhret (1/72), Talih Kuşu (1/73), Tatar Ramazan (1/74), Unutulmaz (1/75), Yaban Gülü (1/76), Yalancisın Sen (1/77), Yersiz Yurtsuz (1/78), Zengin ve Yoksul (1/79), Zerda (1/80).

4N1K İlk Assk (2/1), Adı Mutluluk (2/2), Adı: Zehra (2/3), Ali Ayşe'yi Seviyor (2/4), Araf Zamanı (2/5), Arka Sıradakiler Umut (2/6), Asayis Berkemal (2/7), Așk Yalanı Sever (2/8), Aşk Yeniden (2/9), Aşkın Halleri (2/10), Babam İçin (2/11), Babam Sinıfta Kaldı (2/12), Bana Sevmeyi Anlat (2/13), Benim Hala Umudum Var (2/14), Bir Aile Hikâyesi (2/15), Bir Aşk Hikayesi (2/16), Bir Deli Rüzgar (2/17), Bir Ferhat ile Şirin Hikayesi (2/18), Bir Mucize Olsun (2/19), Bizim Hikaye (2/20), Bu Sayllmaz (2/21), Canan (2/22), Canım Benim (2/23), Çakıl Taşları (2/24), Çifte Saadet (2/25), Çoban Yıldızı (2/26), Çocuklar Duymasın (2/27), Dayan Yüreğim (2/28), Dedemin Dolabı (2/29), Deli Gönül (2/30), Deniz Yıldızı (2/31), Derin Sular (2/32), Dinle Sevgili (2/33), Doktorlar (2/34), Düşler ve Umutlar (2/35), Emanet (2/36), Esaretim Sensin (2/37), Familya (2/38), Fatih Harbiye (2/39), Ferhat İle Şirin (2/40), Görüş Günü Kadınları (2/41), Günahkar (2/42), Harem (2/43), Hayat Sevince Güzel (2/44), Her Yerde Sen (2/45),

Fox Hindistan'da Aşk (2/46), İnadına Aşk (2/47), Kadın (2/48), Kadim Dostum (2/49), Kahireli Palas (2/50), Kalbim Yangın Yeri (2/51), Kalbimdeki Deniz (2/52), Karagül (2/53), Karımın Dediği Dedik Çaldığı Kontrbas (2/54), Kayıtdışı (2/55), Kırlangıç Frrtınası (2/56), Kiraz Mevsimi (2/57), Kirli Beyaz (2/58), Kocamın Ailesi (2/59), Komşular (2/60), Kördüğüm (2/61), Kurşun (2/62), Lale Devri (2/63), Melekler Korusun (2/64), Merhaba Hayat (2/65), Mucize Doktor (2/66), Muhteşem Yüzyll Kösem (2/67), N'olur Ayrllalım (2/68), Nerdesin Birader (2/69), No:309 (2/70), Not Defteri (2/71), O Hayat Benim (2/72), Öğretmen Kemal (2/73), Ömre Bedel (2/74), Ruhumun Aynası (2/75), Rüzgarın Kalbi (2/76), Sana Bir Sır Vereceğim (2/77), Savaşçı (2/78), Sen Benimsin (2/79), Sensiz Yaşayamam (2/80), Şehrin Melekleri (2/81), Şen Yuva (2/82), Şevkat Yerimdar (2/83), Umuda Kelepçe Vurulmaz (2/84), Umutsuz Ev Kadınları (2/85), Vurgun (2/86), Yasak Elma (2/87), Yer Gök Aşk (2/88), Zehirli Sarmaşık (2/89), Zengin Kız Fakir Oğlan (2/90).

Adı Efsane (3/1), Akasya Durağı (3/2), Alın Yazım (3/3), Altın Soylar (3/4), Analı Oğullu (3/5), Ankara'nın Dikmeni (3/6), A.Ș.K (3/7), Annem Uyurken (3/8), Așk-1 Memnu (3/9), Aşk ve Gurur (3/10), Aşk ve Günah (3/11), Babam ve Ailesi (3/12), Bana Artık Hicran De (3/13), Benim Adım Gültepe (3/14), Bes Kardeş (3/15), Bir Bulut Olsam (3/16), Bir Çocuk Sevdim (3/17), Bir Deniz Hikâyesi (3/18), Bir Litre Gözyaşı (3/19), Bir Umut Yeter (3/20), Bizim Yenge (3/21), Bodrum Masalı (3/22), Boynu Bükükler (3/23), Cinayet (3/ 24), Cumaya Kalsa (3/ 25), Çalıkuşu (3/26), Çocuklar Duymasın (3/27), Dostlar Mahallesi (3/28), Evlat Kokusu (3/29), Fatih (3/30), Fatmagül'ün Suçu Ne? (3/31), Gece Gündüz (3/32), Geniş Aile (3/33), Gülizar (3/ 34), Güllerin Savaşı (3/35),

Kanal D Güneşi Beklerken (3/36), Güneş’in Kızları (3/37), Güzel Çirkin (3/38), Hanımın Çiftliği (3/39), Hayatımın Aşkı (3/40), Hayat Mucizelere Gebe (3/41), Hayati ve Diğerleri (3/42), Hayat Şarkısı (3/43), Hıçkırık (3/44), İki Yalancı (3/45), İkizler Memo-Can (3/46), İnadına Yaşamak (3/47), İnsanlık Suçu (3/48), İntikam (3/49), İsimsizler (3/50), Kanıt (3/51), Kanıt: Ateş Üstünde (3/52), Kalbim Ege'de Kaldı (3/53), Kara Kutu (3/54), Kara Yazı (3/ 55), Kayıp (3/56), Kayıp Şehir (3/57), Keşanlı Ali Destanı (3/58), Kızlarım İçin (3/59), Koca Koca Yalanlar (3/60), Kötü Yol (3/61), Kurtlar Vadisi Pusu (3/62), Kuzey Güney (3/63), Küçük Ağa (3/64), Küçük Kadınlar (3/65), Küçük Sırlar (3/66), Leke (3/67), Masum (3/68), Mehmed: Bir Cihan Fatihi (3/69), Merhamet (3/70), Meryem (3/71),Muhteşem İkili (3/72), Mükemmel Çift (3/73), Ne Diyorsun? (3/74), Nuri (3/75), Öyle Bir Geçer Zaman Ki (3/76), Poyraz Karayel (3/77), Sevdanın Bahçesi (3/78), Siyah Beyaz Aşk (3/79), Sultan (3/80), Şeref Meselesi (3/81), Şüphe (3/82), Tatlı İntikam (3/83), Tutsak (3/84), Türkan (3/85), Ulan İstanbul (3/86), Umutsuz Ev Kadınları (3/87), Urfalıyam Ezelden (3/88), Üsküdar'a Giderken (3/89), Vatanım Sensin (3/90), Veda (3/91), Ver Elini Assk (3/92), Vicdan (3/93), Yalan Dünya (3/94), Yaz’ın Öyküsü (3/95), Yıllar Sonra (3/96), Yol Arkadaşım (3/97), Yüzleşme (3/98), Zeytin Tepesi (3/99).

Acı Hayat (4/1), Adını Feriha Koydum (4/2), Ah Kalbim (4/3), Aklın Başına Gelsin (4/4), Aliye (4/5), Benimsin (4/6), Bıçak Sırtı (4/7), Bir Garip Aşk (4/8), Bir Tutam Aşk (4/9), Büyük Yalan (4/10), Canım Ailem (4/11), Deli Divane (4/12), Deli Yürek (4/13), Doktorlar (4/14), Elif (4/15), Ekmek Teknesi (4/16), Feda (4/17), Hayatın Kiyısında (4/18), Hz. Meryem (4/19), Hz. Ömer (4/20), Hz. Yusuf (4/21), İkimizin Yerine (4/22), İki Yabancı (4/23), İstanbul Hatırası (4/24), İşgal (4/25), Kayıp Hayatlar (4/26), Kız

Adres | Address

RumeliDE Dil ve Edebiyat Araşttrmaları Dergisi $\quad$ RumeliDE Journal of Language and Literature Studies Osmanağa Mahallesi, Mürver Ciçeği Sokak, No:14/8 Osmanağa Mahallesi, Mürver Çiçeği Sokak, No:14/8

Kadıköy - ISTANBUL / TÜRKIYE 34714 Kadıköy - ISTANBUL / TURKEY 34714 e-posta: editor@rumelide.com e-mail: editor@rumelide.com,

tel: +90 505 7958124, +90 2167730616 phone: +90 505 7958124, +90 2167730616 

Müziklerin Efendisi (4/31), Ömre Bedel (4/32), Sarı Sarı Liralar (4/33), Sensiz Olmaz (4/34), Sev Beni (4/35), Sevda Masalı (4/36), Sev Yeter (4/37), Sil Baştan (4/38), Sonsuza Dek (4/39), Yabancı Damat (4/40), Yemin (4/41), Yer Gök Aşk (4/42), Yol (4/43), Zerda (4/44).

Acı Aşk (5/1), Acil Aşk (5/2), Adını Feriha Koydum (5/3), Acil Servis (5/4), Adını Kalbime Yazdım (5/5), Ağlatan Dans (5/6), Ah Neriman (5/7), Altın Dağlı (5/8), Analı Oğullu (5/9), Arkadaşlar Iyidir (5/10), Asla Vazgeçmem (5/11), Aşk Ağlatır (5/12), Aşk Ekmek Hayaller (5/13), Aşk ve Gurur (5/14), Balkan Düğünü (5/15), Bebek İşi (5/16), Beni Affet (5/17), Benim İçin Üzülme (5/18), Beyaz Yalan (5/19), Bir Deli Sevda (5/20), Canım Babam (5/21), Cesur Yürek (5/22), Çarpışma (5/23), Çukur (5/24), Deli Saraylı (5/25), Deniz Yıldızı (5/26), Dila Hanım (5/27), Dudaktan Kalbe (5/28), Düşman Kardeşler (5/29), Emir'in Yolu (5/30), Es Es (5/31), Eve Düşen Yıldırım (5/32), Ezel (5/33), Ezra (5/34), Fabrika Kizı (5/35), Firuze (5/36), Gamsız Hayat (5/37), Gece Sesleri (5/38), Gönül Ferman Dinlemiyor (5/39), Gülperi (5/40), Gülümse Yeter (5/41), Gün Akşam Oldu (5/42), İlişki Durumu: Evli (5/43), İlişki Durumu: Karışık (5/44), İçerde (5/45), İstanbul Sokakları (5/46), Kalp Atışı (5/47), Kahramanlar (5/48), Karadağlar (5/49), Karakol (5/50), Klavye Delikanlıları (5/51), Kuzey Yıldızı: İlk Aşk

Show Tv (5/52), Kurtlar Vadisi Pusu (5/53), Lale Devri (5/54), Manyak Dükkan (5/55), Mayıs Kraliçesi (5/56), Mihrap Yerinde (5/57), Melekler (5/58), Muhteşem Yüzyll (5/59), Ne Münasebet (5/60), Nöbet (5/61), Oldu Teşekkürler (5/62), Otel Divane (5/63), Oyunbozan (5/64), Önce Vatan (5/65), Pis Yedili (5/66), Salih Kuşu (5/67), Servet (5/68),Sensiz Olmaz (5/69), Sevdaluk (5/70), Sinif (5/71), Suskunlar (5/72), Türk Malı (5/73), Ustura Kemal (5/74), Yeni Gelin (5/75), Yllanların Öcü (5/76), Yuvamdaki Düşman (5/77), Yüz (5/78), Zemheri (5/79).

Acayip Hikayeler (6/1), Adını Sen Koy (6/2), Aile Reisi (6/3), Akasya Durağı (6/4), Anne (6/5), Anneler ve Kızları (6/6), Aşkın Bedeli (6/7), Aşktan Kaçılmaz (6/8), Ateş Böceği (6/9), Ateşe Yürümek (6/10), Avlu (6/11), Ay Işığı (6/12), Ay Tutulması (6/13), Baba Ocağı (6/14), Babamın Günahları (6/15), Babalar ve Evlatlar (6/16), Behzat Ç. (6/17), Beni Affet (6/ 18), Benim Annem Bir Melek (6/19), Benim Hala Umudum Var (6/20), Benim Tatlı Yalanim (6/21), Ben de Özledim (6/22), Bir Çocuk Sevdim (6/23), Bir Erkek Bir Kadın (6/24), Bir Ömür Yetmez (6/25), Börü (6/26), Canımın İçi (6/27), Cennetin Sirları (6/28), Cesur Ve Güzel (6/29), Çember (6/30), Çilek Kokusu (6/31), Çocuk (6/32), Deniz Kızı (6/33), Dila Hanım (6/34), Dolunay (6/35), Düriye'nin Gügüüleri (6/36), Erkenci Kuş (6/37), Evlerden Biri (6/38), Fazilet Hanım ve Kızları (6/39), Firar (6/40), Gecenin Kraliçesi (6/41), Geniș Aile (6/42), Göç Zamanı (6/43), Gönül İșleri (6/44), Güvercin (6/45), Güzel Köylü (6/46), Hanım Köylü (6/47), Hatırla Sevgili (6/48), Hayat Bazen Tatlıdır (6/49), Hayat Sırları (6/50), İbreti Alem (6/51), İçimdeki Frrtına (6/52), İffet (6/53), İhanet (6/54), İstanbul'un Çocukları (6/55), İstanbullu Gelin $(6 / 56)$, İşler Güçler $(6 / 57)$, Jet Sosyete $(6 / 58)$, Kaçak Gelinler (6/59), Kaderimin Yazıldığ Gün (6/6o), Kalbim Dört Mevsim (6/61), Kalbimin Sultanı (6/62), Kara Sevda (6/63), Kardeş Çocukları (6/64), Kardeş Payı (6/65), Kiralık Aşk (6/66), Koyu Kırmızı (6/67), Kurt Seyit ve Şura (6/68), Kurtlar Vadisi Pusu (6/69), Kuzgun (6/70), Küçük Hesaplar (6/71), Küçük Kadınlar (6/72), Küçük Sırlar (6/73), Kül ve Ateş (6/74), Makber (6/75), Medcezir (6/76), Muhteşem Yüzyll (6/77), Nefes Nefese (6/78), Papatya (6/79), Paramparça (6/80), Sefirin Kızı (6/81), Serçe Saray (6/82), Sevdim Seni Bir Kere (6/83), Sevgili Geçmiş (6/84), Sirat (6/85), Sihirli Annem (6/86), Siyah İnci (6/87), Sudan Bıkmış Balıklar (6/88), Sonbahar (6/89), Şahane Damat (6/90), Tatlı Küçük Yalancılar (6/91), Ufak Tefek Cinayetler (6/92), Urfalıyam Ezelden (6/93), Yalancı Bahar (6/94), Yıldızlar Şahidim (6/95), Yol Arkadaşım (6/96), Yüksek Sosyete (6/97).

6 Mantı (7/1), Abur Cubur (7/2), Acemi Müezzin (7/3), Adım Bayram Bayram (7/4), Adını Sen Koy (7/5), Ah Kalbim (7/6), Alayına İsyan (7/7), Aşkın Kanunu (7/8), Avrupa Avrupa (7/9) Aynadaki Düşman (7/10), Ayrılık (7/11), Baba Candır (7/12), Başrolde Aşk (7/13), Beni Böyle Sev (7/14), Bir Yastıkta (7/15), Bir Yusuf Masalı (7/16), Bir Zamanlar Osmanlı (7/17), Böyle Bitmesin (7/18), Bulutların Ötesi (7/19), Büyük Sürgün Kafkasya (7/20), Cam Kırıkları (7/21), Canını Sevdiğim İstanbul'u (7/22), Çılgın Kanal (7/23), Çocukluk Günleri (7/24), Diriliş: Ertuğrul (7/25), Elde Var Hayat (7/26), En Uzun Yüzyll (7/27), Esir Sultan (7/28), Eski Hikaye (7/29), Evvel Zaman Hikayesi (7/30), Gökkuşağı Çocukları (7/31), Gönül Hırsızı (7/32), Gurbette Aşk (7/33), Halil İbrahim Sofrası (7/34), Halka (7/35), Hangimiz Sevmedik (7/36), Hanımeli Sokağı (7/37), Hayat Ağacı (7/38), Hayata Beş Kala (7/39), Heradot Cevdet (7/40), Hesaplaşma (7/41), Hicran Yarası (7/42), İstanbul'da Aşık Oldum (7/43), Karşı Köyün Delisi (7/44), Kaybedenler

\section{Adres $\mid$ Address}

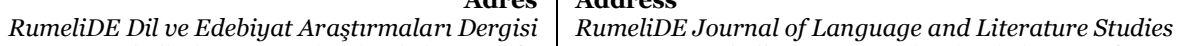

Osmanağa Mahallesi, Mürver Çiçeği Sokak, No:14/8 $\quad$ Osmanağa Mahallesi, Mürver Çiçeği Sokak, No:14/8

Kadıköy - İSTANBUL / TÜRKIYE 34714 Kadıköy - ISTANBUL / TURKEY 34714 e-posta: editor@rumelide.com

tel: +90 505 7958124, +90 2167730616 phone: +90 505 7958124, +90 2167730616 
(7/45), Kayıp Aranıyor (7/46), Kızıl Elma (7/47), Komiser Rex (7/48), Korkma (7/49), Kurt Kanunu (7/50), Küçük Hanımefendi (7/51), Küstüm Çiçeği (7/52), Leyla ile Mecnun (7/53), Lise Devriyesi (7/54), Mavi Kelebekler (7/55), Mazi Kalbimde Yaradır (7/56), Mehmetçik Kut'ül Amare (7/57), Milat (7/58), Mor Menekşeler (7/59), Osmanlı Tokadı (7/60), Prensin Şarkısı (7/61), Sakarya Firat (7/62), Sarayın Incisi (7/63), Seddülbahir 32 Saat (7/64), Seksenler (7/65), Sende Gitme (7/66), Sevda Kuşun Kanadında (7/67), Sinıf (7/68), Son Çıkış (7/69), Son Destan (7/70), Sudan Sebepler(7/71), Şimdi Onlar Düşünsün (7/72), Şubat (7/73), Tacir (7/74), Tek Yürek (7/75), Yalaza (7/76), Yamak Ahmet (7/77), Yapma Diyorum (7/78), Yedi Güzel Adam (7/79), Yedikule Hayat Yokuşu (7/80) Yeniden Başla (7/81), Yerden Yüksek (7/82), Yeşil Deniz (7/83), Yol Ayrımı (7/84), Yunus Emre Aşkın Yolculuğu (7/85), Zengin Kız Fakir Oğlan (7/86), Zoraki Başkan (7/87).

\section{Address}

RumeliDE Journal of Language and Literature Studies

Osmanağa Mahallesi, Mürver Çiçeği Sokak, No:14/8

Kadıköy - ISTANBUL / TURKEY 34714

e-mail: editor@rumelide.com

phone: +90 505 7958124, +90 2167730616 